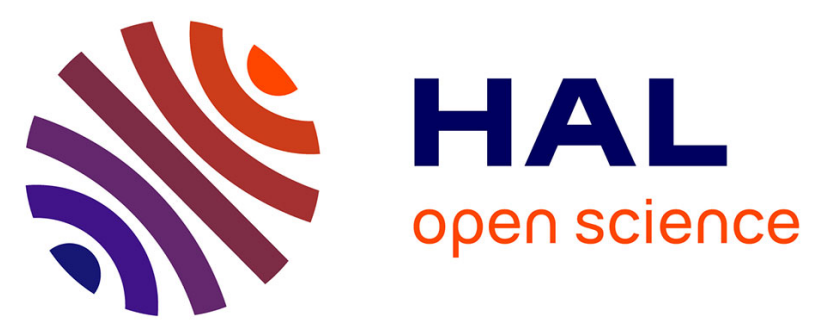

\title{
A di-Copper Peptidyl Complex Mimics the Activity of Catalase, a Key Antioxidant Metalloenzyme
}

Koudedja Coulibaly, Marion Thauvin, Adyn Melenbacher, Clara Testard, Evangelia Trigoni, Amandine Vincent, Martin J Stillman, Sophie Vriz, Clotilde Policar, Nicolas Delsuc

\section{To cite this version:}

Koudedja Coulibaly, Marion Thauvin, Adyn Melenbacher, Clara Testard, Evangelia Trigoni, et al.. A di-Copper Peptidyl Complex Mimics the Activity of Catalase, a Key Antioxidant Metalloenzyme. Inorganic Chemistry, 2021, Online ahead of print. 10.1021/acs.inorgchem.0c03718 . hal-03262072

\section{HAL Id: hal-03262072 https://hal.science/hal-03262072}

Submitted on 16 Jun 2021

HAL is a multi-disciplinary open access archive for the deposit and dissemination of scientific research documents, whether they are published or not. The documents may come from teaching and research institutions in France or abroad, or from public or private research centers.
L'archive ouverte pluridisciplinaire HAL, est destinée au dépôt et à la diffusion de documents scientifiques de niveau recherche, publiés ou non, émanant des établissements d'enseignement et de recherche français ou étrangers, des laboratoires publics ou privés. 


\title{
A Di copper Peptidyl Complex Mimics the Activity of Catalase, a Key Antioxidant Metalloenzyme
}

\author{
Koudedja Coulibaly, ${ }^{\ddagger}$ Marion Thauvin, ${ }^{\S}{ }^{\#}$ Adyn Melenbacher, ${ }^{\perp}$ Clara Testard, ${ }^{\ddagger}$ Evangelia Trigoni, ${ }^{\ddagger}$ \\ Amandine Vincent, ${ }^{\ddagger}$ Martin J. Stillman, ${ }^{\perp}$ Sophie Vriz, $,{ }^{\S}, /$ Clotilde Policar,${ }^{\ddagger}$ Nicolas Delsuc ${ }^{*}$, \\ ${ }^{\ddagger}$ Laboratoire des biomolécules, LBM, Département de chimie, Ecole normale supérieure, PSL University, Sorbonne Univer- \\ sité, CNRS, 75005 Paris, France \\ ${ }^{\S}$ Centre Interdisciplinaire de Recherche en Biologie (CIRB), CNRS UMR7241/INSERM U1050/Collège de France, 75231 \\ Paris, Cedex 05, France \\ \# Sorbonne Université, 4 place Jussieu, 75005 Paris, France \\ ${ }^{\perp}$ Department of Chemistry, The University of Western Ontario, London, ON N6A 5B7, Canada \\ " Université de Paris, Faculty of Science - 75006 Paris, France
}

KEYWORDS Catalase mimic, copper complex, peptide, combinatorial chemistry, reactive oxygen species, antioxidant, electrospray ionization mass spectrometry.

\begin{abstract}
Catalases (CAT) are antioxidant metalloenzymes necessary for life in oxygen-metabolizing cells to regulate $\mathrm{H}_{2} \mathrm{O}_{2}$ concentration by accelerating its dismutation. Many physio-pathological situations are associated with oxidative stress resulting from $\mathrm{H}_{2} \mathrm{O}_{2}$ overproduction during which antioxidant defenses are overwhelmed. We have used a combinatorial approach associated with an activity-based screening to discover a first peptidyl di copper complex mimicking CAT. The complex was studied in detail and characterized for its CAT activity both in solution and in cells using different analytical methods. The complex exhibited CAT activity in solution and, more interestingly, on HyPer HeLa cells which possess a genetically encoded ratiometric fluorescent sensors of $\mathrm{H}_{2} \mathrm{O}_{2}$. These results highlight the efficiency of a combinatorial approach for the discovery of peptidyl complexes that exhibit catalytic activity.
\end{abstract}

\section{INTRODUCTION}

Aerobic organisms generate their energy through the reduction of $\mathrm{O}_{2}$ to $\mathrm{H}_{2} \mathrm{O}$. During this process, reactive oxygen species (ROS) are continuously formed. The redox cascade initially forming $\mathrm{O}_{2}{ }^{--}$leads to the subsequent formation of $\mathrm{H}_{2} \mathrm{O}_{2} \cdot \mathrm{H}_{2} \mathrm{O}_{2}$ then dissociates to the hydroxyl radical $(\cdot \mathrm{OH})$ in mitochondria and/or peroxisomes. ROS play a key role in a range of different mechanisms such as cell proliferation and cell differentiation. ${ }^{1-3}$ They are very reactive molecules with strongly oxidizing properties. The most reactive and damaging is $\bullet \mathrm{OH}$. Although $\mathrm{H}_{2} \mathrm{O}_{2}$ and $\mathrm{O}_{2}{ }^{--}$are not as reactive, they can become cytotoxic if their intracellular concentration exceeds a limiting threshold, overwhelming the protective pathways and leading to oxidative stress. Oxidative stress is known to be implicated in many physio-pathological situations. ${ }^{4-9}$ Although the presence of ROS is not always the sole cause of these different diseases, it nevertheless is a major contributor. It is, therefore, essential to control ROS concentrations in order to limit their deleterious effects. Antioxidant defenses protect biological systems from free radical toxicity and prevent damage due to excessive concentrations of ROS. This can be achieved either by controlling the production of ROS and/or by controlling the elimination of ROS. Antioxidant defenses include stoichio- metric scavengers such as vitamins $\mathrm{C}$ and $\mathrm{E}$, glutathione and metalloenzymes like superoxide dismutase (SOD), ${ }^{10-15}$ catalase (CAT), ${ }^{16,17}$ glutathione peroxidase (GPx), and glutathione reductase $(\mathrm{GR}) .^{18,19}$

Despite the fact that higher concentrations of $\mathrm{H}_{2} \mathrm{O}_{2}$ than $\mathrm{O}_{2}{ }^{--}$or $\mathrm{OH} \bullet$ are tolerated in cells, the intracellular concentrations of $\mathrm{H}_{2} \mathrm{O}_{2}$ must be tightly controlled at 1-100 nM. ${ }^{3}$ CAT is one of the enzymes involved in the regulation of $\mathrm{H}_{2} \mathrm{O}_{2}$ concentration by accelerating its dismutation. ${ }^{20}$ During this reaction, one molecule of $\mathrm{H}_{2} \mathrm{O}_{2}$ is reduced into two molecules of $\mathrm{H}_{2} \mathrm{O}$, and a second molecule of $\mathrm{H}_{2} \mathrm{O}_{2}$ is oxidized into $\mathrm{O}_{2}{ }^{21}$ CAT is present in all aerobic species where it has been sought for. ${ }^{17}$ To date, two classes of catalase have been identified: a monofunctional heme CAT (HemeCAT), and a non-heme dinuclear manganese CAT (MnCAT). ${ }^{20-23}$ The dismutation of $\mathrm{H}_{2} \mathrm{O}_{2}$ consists of two bi-electronic processes, requiring a bi-electronic catalyst. In the case of the HemeCAT, the iron and porphyrin ligand both participate to the two electron exchanges, cycling between an $(\mathrm{P}) \mathrm{Fe}^{\mathrm{III}}$ resting state and $\mathrm{a}\left(\mathrm{P}^{\cdot+}\right) \mathrm{Fe}^{\mathrm{IV}}=\mathrm{O}$ high oxidation state, (also called compound I). ${ }^{24,25}$ MnCAT was more recently discovered in lactic acid bacteria ${ }^{23,26,27}$ which lack heme and cytochrome. It has been demonstrated that MnCAT possesses a binuclear manganese active site which cycles between the reduced state $\mathrm{Mn}^{\mathrm{II}}-\mathrm{Mn}^{\mathrm{II}}$ and the oxidized state $\mathrm{Mn}^{\mathrm{III}}-\mathrm{Mn}^{\mathrm{III}}$, 
affording the two electrons exchange required for the dismutation reaction..$^{20,22,23}$

Small molecular complexes mimicking CAT have been developed to reduce oxidative stress in pathological conditions. ${ }^{28-30}$ These bioinspired mimics are thus mainly mononuclear (Mn or $\mathrm{Fe}$ ) porphyrin derivatives or dinuclear manganese complexes analogous to the active site of HemeCAT or MnCAT, respectively. $^{29}$ Dinuclear $\mathrm{Mn}$ complexes bioinspired from MnCAT are alkoxo, phenoxo, or oxo/carboxylato bridged complexes. In an excellent review, Signorella and Hureau have reported that besides the redox potentials of the metal ions key to catalytic $\mathrm{H}_{2} \mathrm{O}_{2}$ dismutation, the efficacy of the complexes is associated with the presence of an intramolecular base to assist in deprotonation. In addition, the presence of a vacant site on the $\mathrm{Mn}$ ion is required to coordinate $\mathrm{H}_{2} \mathrm{O}_{2}$, but the complex stability is reduced by the protonation of the bridging ligand. ${ }^{31}$ Few mononuclear copper complexes ${ }^{30,32-36}$ have been reported as CAT mimics as well but examples of dinculear copper complexes are very rare. ${ }^{37-40}$ Generally, CAT mimics have been studied in organic solvents or have exhibited activity only at $\mathrm{pH}$ above 8 . So far, contrarily to SOD mimics, no peptidyl complexes mimicking CAT have been reported, whatever the metal ion. ${ }^{41-44}$ This may be explained by the difficulty to rationally design short peptides able to bind two metal cations (to afford the two required electrons) with appropriate redox potentials and affinities. However, peptidyl ligands are of great interest since their synthesis is very versatile, they are biocompatible and water soluble. But it seems highly complicated to design Mn-based peptidyl complexes since peptide affinity for $\mathrm{Mn}(\mathrm{II})$ is usually in the $10^{3}-10^{6}$ range at physiological $\mathrm{pH}$ even for quite long sequences. ${ }^{45-47}$ In contrast, short peptide sequences have been described to bind $\mathrm{Cu}$ (II) with high affinities (ca. $\left.10^{12}-10^{15}\right) .^{42,48,49}$ In this manuscript, we describe implementation of a combinatorial approach to synthesize a library of copper complexes, associated with an activity-based screening. This led to the discovery of the first peptidyl di copper complex mimicking CAT redox chemistry. The selected dinuclear copper complex was studied in detail and characterized for its CAT activity in solution and in cells. Very interestingly, despite moderate intrinsic catalysis constants, this complex was efficacious in a cellular assay.

\section{RESULTS AND DISCUSSION}

\section{Screening process}

To generate a large number of small peptidyl metal complexes, a peptide library was synthesized on a solid support by a split-and-pool combinatorial method leading to a one-beadone-peptide library (Scheme S1). Inspired by the method developed by B. Imperiali who discovered a lanthanide binding $\operatorname{tag}^{50}$ which we have recently implemented for the discovery of peptidyl SOD mimics efficient in cells, ${ }^{43}$ the peptide library was designed to generate peptides that strongly bind copper. Peptides of the library have a general sequence Ac$\mathrm{PX}_{2} \mathrm{X}_{3} \mathrm{KHX}_{6} \mathrm{LH}-\mathrm{OH}$ where $\mathrm{X}$ indicates places where diversity was introduced. Amino acids possessing coordinating side chains (aspartate or glutamate, tyrosine and histidine) and noncoordinating side chains (glycine and arginine) at positions $X_{n}$ were chosen to explore the properties of the $5^{3}$ peptides (Figure. 1A). After side chain deprotection using trifluoroacetic acid, the supported peptides were incubated in a solution of $\mathrm{CuSO}_{4}(10 \mathrm{mM})$ in HEPES buffer (50 mM, pH 7.5) for $2 \mathrm{hr}$. The beads were then washed with buffer and EDTA $(25 \mathrm{mM}$, $\mathrm{pH} 8$ ), a strong competitor ${ }^{51}$ for $\mathrm{Cu}$ (II) chelation, to increase differential selectivity. This additional washing step allows for the removal of more loosely bound copper ions and/or the release of copper from less inert complexes. However, note that this step does not ensure that the remaining complexes are more stable or inert than the EDTA-Cu complex since it is a heterogenous process. To perform the screening of the peptidyl complexes library, the beads carrying the peptidyl complexes were immobilized in a $2 \%$ agarose gel according to the method developed by Nitz et al. (Figure 1B). ${ }^{50}$ The gel was then irradiated using UV light $(254 \mathrm{~nm})$ for 15 minutes to release the portion of peptidyl complexes that were linked to the resin via a photocleavable linker ( $c a$. 10\%, Figure 1A). The diffusion of the complexes from the bead within the gel increased their accessibility and the surface area where the potential CAT mimics are present. To screen the peptidyl metal catalysts according to their CAT activity, a protocol inspired from the functional assay used to characterize CAT on electrophoretic gels was implemented. ${ }^{52}$

A

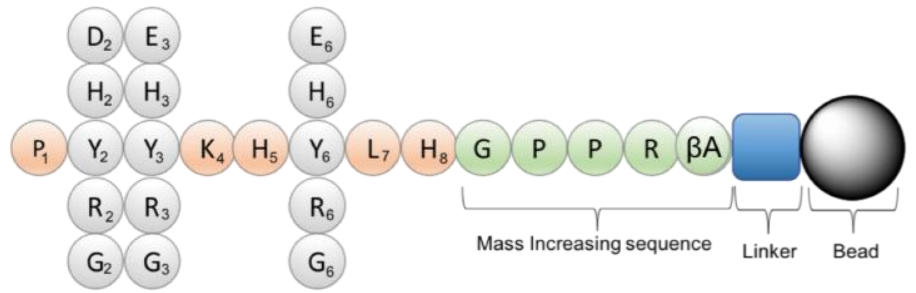

B

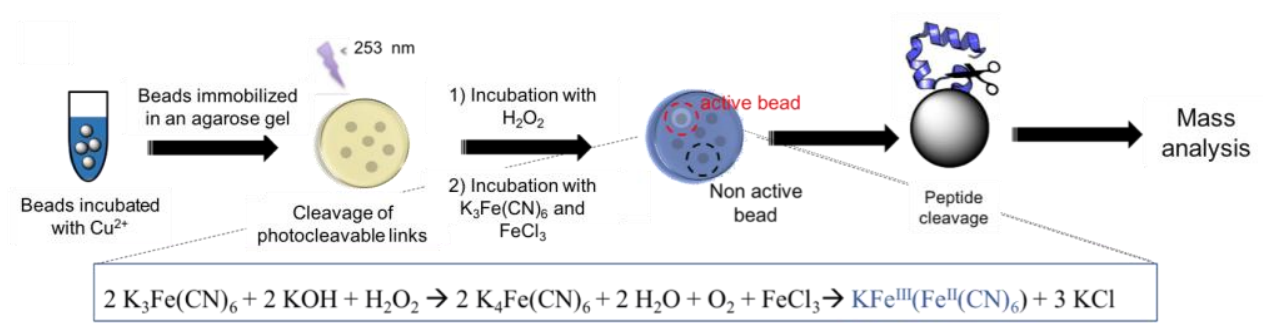

Figure 1. (A) Peptide library on bead. Beads are Tentagel macrobeads. Two linkers were introduced: 10\% of 4-nitrophenylalanine cleaved under UV irradiation and $90 \%$ of 4-(hydroxymethyl)benzoic acid (HMBA) cleaved in basic conditions. (B) Scheme of peptidyl complexes screening using a colorimetric activity-based assay. 
The gel was incubated with a solution of $\mathrm{H}_{2} \mathrm{O}_{2}(0.015 \%)$ for $10 \mathrm{~min}$ and subsequently with two ferric complexes, $\mathrm{K}_{3} \mathrm{Fe}(\mathrm{CN})_{6}$ and $\mathrm{FeCl}_{3}$. In the presence of $\mathrm{H}_{2} \mathrm{O}_{2}, \mathrm{~K}_{3} \mathrm{Fe}(\mathrm{CN})_{6}$, an orange-yellow solution, is reduced to $\mathrm{K}_{4} \mathrm{Fe}(\mathrm{CN})_{6}$, which then reacts with $\mathrm{FeCl}_{3}$ to give Prussian blue $\left(\mathrm{K}_{3} \mathrm{Fe}^{\mathrm{III}}\left(\mathrm{Fe}^{\mathrm{II}}(\mathrm{CN})_{6}\right)\right)$, which has a deep blue color. ${ }^{52}$ The medium around the bead is depleted in $\mathrm{H}_{2} \mathrm{O}_{2}$ when a CAT mimic is present, because of the fast dismutation of $\mathrm{H}_{2} \mathrm{O}_{2}$. This prevents the reduction of $\mathrm{K}_{3} \mathrm{Fe}(\mathrm{CN})_{6}$ and the formation of Prussian blue. A colorless area around the bead thus indicates that an active CAT mimic is present. It is worth mentioning that when the beads were not incubated in the copper solution, no positive results were obtained. This supports the fact that if iron complexes were formed from the $\mathrm{K}_{3} \mathrm{Fe}(\mathrm{CN})_{6}$ and $\mathrm{FeCl}_{3}$, they are not active for $\mathrm{H}_{2} \mathrm{O}_{2}$ dismutation. Using this procedure, sixteen beads from the pool of 600 tested were selected, removed from the gel, and extensively washed with EDTA to eliminate the copper. The peptides were then cleaved from the resin and analyzed by MALDI-TOF mass spectrometry (Figure 1B). To enable the unambiguous elucidation of the peptide sequence using a single mass spectrometric analysis, the method developed by Griesinger et al., ${ }^{53}$ adapted by Imperiali et al. ${ }^{50}$ which we used previously $^{43}$ was employed (Figure. S1). Among the sixteen beads collected, the primary sequence could be determined for twelve peptides (Table $\mathrm{S} 1, \mathrm{~A}$ ). Interestingly, at positions $\mathrm{X}_{2}$ and $X_{3}$, coordinating amino acids were mainly found with histidine being the more often observed amino acid at position $\mathrm{X}_{2}$ and tyrosine at position $\mathrm{X}_{3}$. On the contrary, at position $\mathrm{X}_{6}$ non-coordinating amino acids were mainly observed (Table S1, B). Importantly, the peptide sequence PHYKHRLH (called CATm1) was found twice and a third, with a sequence (PHYKHGLH) that differs only by the non-coordinating amino acid at position $\mathrm{X}_{6}$ was also found. CATm1 was selected for further investigations.

\section{Hit complex characterization}

The CATm1- $\mathrm{Cu}^{2+}$ complex was first investigated in solution in a MOPS buffer (50 mM), a fairly low complexing buffer, at pH 7.5 by Electron Paramagnetic Resonance (EPR) spectroscopy. Frozen solutions with different CATm1:Cu${ }^{2+}$ ratios ranging from 1:0.5 to 1:5 were prepared and recorded at low temperature $(\mathrm{T}=110 \mathrm{~K})$. The EPR spectrum obtained in the presence of 0.5 equivalent of $\mathrm{Cu}^{2+}$, where the observed parameters were $\mathrm{g} / /=2.26>\mathrm{g} \perp=2.06$ and $\mathrm{A} / /=0.0178 \mathrm{~cm}^{-1}$, indicates a square planar geometry (Figure $2 \mathrm{~A}){ }^{54-56}$ This spectrum suggests a coordination site very similar to the copper coordination site of mixed N,O ligand. ${ }^{57,58}$ Upon addition of $\mathrm{Cu}^{2+}$, the intensity of the signal increased and a second set of signals appeared gradually. This suggests that a first complex may be formed and that above one equivalent, a second copper ion is also bound (Figure 2A). A titration performed in MOPS buffer (50 mM, pH 7.5) by UV-vis circular dichroism spectroscopy confirmed this hypothesis: upon addition of $\mathrm{Cu}^{2+}$, the bands at $230 \mathrm{~nm}$ and at $260 \mathrm{~nm}$ increased up to two equivalents and reached a plateau (Figure $2 \mathrm{~B}$ ).

The key parameter for an efficient catalysis of $\mathrm{H}_{2} \mathrm{O}_{2}$ dismutation is the two-electron redox potential of the CAT. The redox potential must lie between the potentials of the $\mathrm{O}_{2} / \mathrm{H}_{2} \mathrm{O}_{2}$ and $\mathrm{H}_{2} \mathrm{O}_{2} / \mathrm{H}_{2} \mathrm{O}$ couples that are $0.28 \mathrm{~V}$ and $1.35 \mathrm{~V}$ vs. NHE, respectively. ${ }^{59}$ The CATm1- $\mathrm{Cu}^{2+}$ complex was examined by cyclic voltammetry in MOPS buffer $(50 \mathrm{mM})$ at $\mathrm{pH}$ 7.5. For a $1: 2 \mathrm{CATm} 1: \mathrm{Cu}(\mathrm{II})$ ratio, the mixture exhibited an anodic potential that differs from those of $\mathrm{Cu}^{2+}$ and CATm1 in solution, providing evidence that at least one complex is formed (Figure 3A and S4). The non-Nernstian shape of the waves is more likely due to a slow electron transfer, which is often the case for peptidyl copper complexes. ${ }^{60,61}$ A titration was performed by electrochemistry (Figure 3A and B). Upon addition of $\mathrm{Cu}^{2+}$, the current corresponding to the anodic potential (at ca. $0.57 \mathrm{~V}$ vs. NHE) increased linearly up to ca. 2 equivalents (Figure 3C left). Interestingly, after 2 equivalents, the slope was modified (Figure 3C), showing that after a 1:2 ratio, the system behaved differently. The continuous increase of the current after 2 equivalents may be attributed to MOPS$\mathrm{Cu}$ complexes. In addition, above ca. 1:2 ratio, the current at the potential corresponding to anodic re-dissolution of $\mathrm{Cu}^{0}$ adsorbed onto the electrode appeared at $c a$. $0.24 \mathrm{~V} / \mathrm{NHE}$, highlighting the fact that the peptide was unable to bind more than two copper cations (Figure 3B yellow to red). The titration was also performed in TRIS buffer $(50 \mathrm{mM}, \mathrm{pH} 7.5)$, which is considered to bind copper with a higher affinity than MOPS buffer. ${ }^{62,63}$ Interestingly, the same trend was observed except that the peak corresponding to the anodic redissolution appeared before 2 equivalents, probably because of the presence of a TRIS-Cu complex (Figure S5).
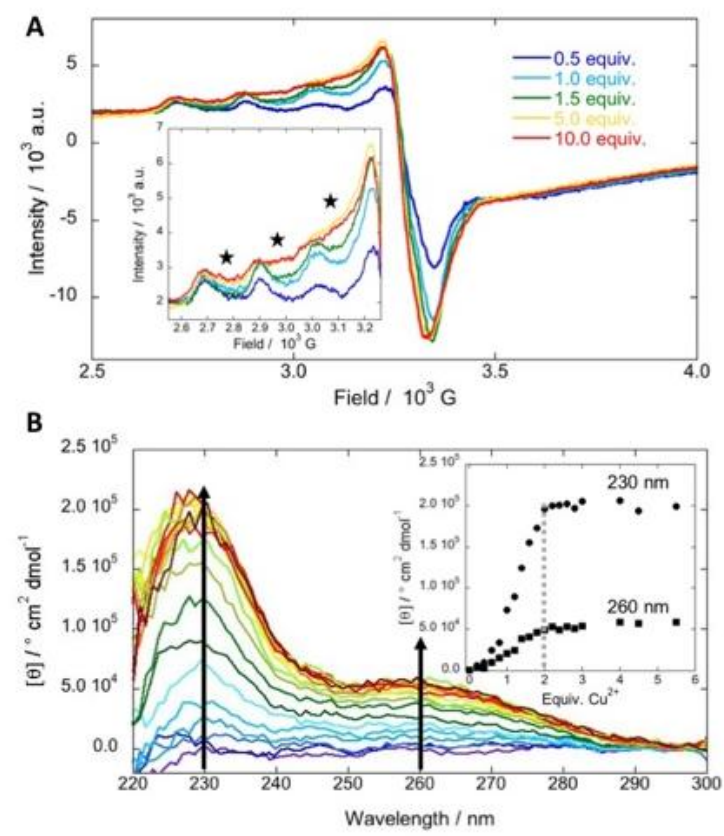

Figure 2. (A) Electron Paramagnetic Resonance spectra in MOPS buffer $\left(50 \mathrm{mM}, \mathrm{pH} 7.5,25^{\circ} \mathrm{C}\right.$, glycerol $\left.10 \%\right)$ of a mixture $\mathrm{CATm} 1: \mathrm{Cu}(\mathrm{OAc})_{2}$ at different ratios, $[\mathrm{CATm} 1]=200 \mu \mathrm{M}, \mathrm{T}=110 \mathrm{~K}$. The inset shows a zoom with the new set of signals indicated with stars. Note that $\mathrm{Cu}(\mathrm{OAc}) 2$ was silent in our conditions as already reported. ${ }^{64}$ (B) CATm1 titration with $\mathrm{Cu}^{2+}$ by UV-vis circular dichroism in MOPS buffer $(50 \mathrm{mM}, \mathrm{pH} 7.5$, $\left.25^{\circ} \mathrm{C}\right),[\mathrm{CATm} 1]=200 \mu \mathrm{M}, \mathrm{T}=25^{\circ} \mathrm{C}$. The inset shows the evolution of the two maxima at 230 and $260 \mathrm{~nm}$ upon $\mathrm{Cu}^{2+}$ addition. The plateau is reached after two equivalents of $\mathrm{Cu}^{2+}$.

All together these results suggest that at $\mathrm{pH} 7.5, \mathrm{CATm} 1$ is able to bind 2 copper(II) cations with different affinities. The reduction and oxidation potentials of the complex were measured at $0.12 \mathrm{~V} / \mathrm{NHE}$ and $0.57 \mathrm{~V} / \mathrm{NHE}$, respectively, and are thus in the correct range to catalyze $\mathrm{H}_{2} \mathrm{O}_{2}$ dismutation. In the same way, the titration performed by cyclic voltammetry at $\mathrm{pH}$ 7.0 in MOPS buffer $(50 \mathrm{mM})$ indicated that, at this $\mathrm{pH}$, a 1:2 
complex was also formed with a second site showing a weaker affinity constant (Figure S6).
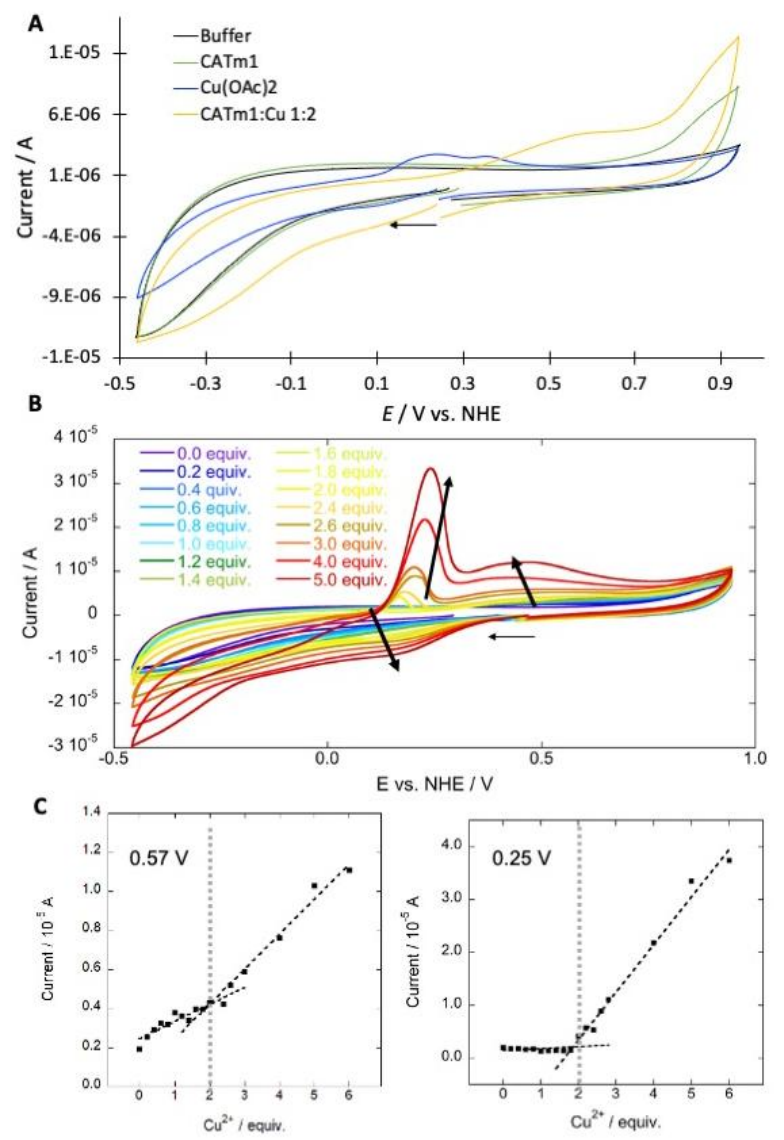

Figure 3. Cyclic voltammetry in MOPS buffer $(50 \mathrm{mM}, \mathrm{pH}$ $\left.7.5,25^{\circ} \mathrm{C}\right)$. (A) Voltammograms of CATm1 (1 $\left.\mathrm{mM}\right)$, CATm1: $\mathrm{Cu}^{2+} 1: 2(1 \mathrm{mM})$ and $\mathrm{Cu}(\mathrm{OAc})_{2}(2 \mathrm{mM})$. (B) Titration of CATm1 $(1 \mathrm{mM})$ by $\mathrm{Cu}(\mathrm{OAc})_{2}(\mathrm{C})$ Evolution of the current at the anodic potential $0.57 \mathrm{~V}$ vs NHE (left) and at the potential corresponding to the anodic re-dissolution $(0.24 \mathrm{~V}$, right $)$. Working electrode: Glassy carbon ( $3 \mathrm{~mm}$ diameter), counter electrode: Platinum, reference electrode: SCE. Scan rate of $100 \mathrm{mV} / \mathrm{s}$, the small arrow indicates the scanning direction and arrows in bold, the evolution of the waves upon addition of $\mathrm{Cu}(\mathrm{OAc})_{2}$

\section{Dinuclear complex stability}

In order to obtain further insight into the stability of this $1: 2$ complex, the apparent dissociation constants were determined by isothermal titration calorimetry (ITC) at $\mathrm{pH} 7$ and 7.5 in MOPS buffer $(50 \mathrm{mM})$. At $\mathrm{pH} 7$, the thermogram obtained was successfully fitted with a " 2 independent sites" model leading to apparent dissociation constants of about $\mathrm{K}_{\mathrm{d} 1}=1.0 \pm$ $0.310^{-6}$ and $\mathrm{K}_{\mathrm{d} 2}=1.1 \pm 0.210^{-5}$, thus confirming that the peptide is able to bind two copper(II) ions with a second site exhibiting a weaker affinity constant (Figure S7, Table 1). The first complexion reaction has a large favorable enthalpic component $\left(\Delta \mathrm{H}_{1}=-47.2 \pm 0.7 \mathrm{~kJ} \mathrm{~mol}^{-1}\right)$ and an unfavorable entropic component $\left(-\mathrm{T} \Delta \mathrm{S}_{1}=12.9 \pm 0.1 \mathrm{~kJ} \mathrm{~mol}^{-1}\right)$, whereas it is the opposite for the second site $\left(\Delta \mathrm{H}_{2}=14.0 \pm 0.9 \mathrm{~kJ} \mathrm{~mol}^{-1}\right.$ and $-\mathrm{T} \Delta \mathrm{S}_{2}=-42.3 \pm 0.6 \mathrm{~kJ} \mathrm{~mol}^{-1}$ ) leading to overall Gibbs free energies of -34.3 and $-28.3 \mathrm{~kJ} \mathrm{~mol}^{-1}$ for the first and the second site, respectively. The first complexation reaction is more favorable than the second one which is entropically driven
(Figure S7, Table 1). At pH 7.5, $\mathrm{Cu}(\mathrm{OAc})_{2}$ titration measured by ITC did not allow for the measurement of the binding constants of the two sites (Figure S8 A).

Table 1. Thermodynamic parameters for complexation of $\mathrm{Cu}(\mathrm{OAc})_{2}$ with CATm1 measured using ITC (average of two independent experiments \pm SEM) at $\mathrm{pH} 7.0$, fluorescence spectrometry at $25^{\circ} \mathrm{C}$ (average of three independent experiments \pm SEM) and mass spectrometry at $\mathrm{pH}$ 7.5. Conditional dissociation constants were calculated considering competition with the buffer (see SI) ${ }^{65}$

\begin{tabular}{lccc}
\hline & $\mathrm{pH} 7.0$ & \multicolumn{2}{c}{$\mathrm{pH} 7.5$} \\
\cline { 3 - 4 } & MOPS & MOPS & $\mathrm{NH}_{4} \mathrm{HCO}_{2}$ \\
\hline $1^{\text {st }}$ Site & & & \\
$\mathrm{n}_{1}$ & $0.88 \pm 0.08$ & & \\
$\Delta \mathrm{H}_{1}\left(\mathrm{~kJ} \mathrm{~mol}^{-1}\right)$ & $-47.2 \pm 0.7$ & & \\
$\Delta \mathrm{S}_{1}\left(\mathrm{~J} \mathrm{~mol}^{-1} \mathrm{~K}^{-1}\right)$ & $-43.3 \pm 0.4$ & & \\
${ }^{\text {app }} \mathrm{K}_{\mathrm{d} 1}$ & $1.0 \pm 0.310^{-6}$ & $2.8 \pm 0.610^{-6}$ & $2.510^{-9[\mathrm{a}]}$ \\
${ }^{\text {cond }} \mathrm{K}_{\mathrm{d} 1}$ & $4.8 \pm 1.410^{-9}$ & $7.9 \pm 0.510^{-9}$ & $2.510^{-9[\mathrm{a}]}$ \\
\hline $2^{\text {nd }} \mathrm{Site}$ & & & \\
$\mathrm{n}_{2}$ & $1.04 \pm 0.04$ & & \\
$\Delta \mathrm{H}_{2}\left(\mathrm{~kJ} \mathrm{~mol}^{-1}\right)$ & $14.0 \pm 0.9$ & & \\
$\Delta \mathrm{S}_{2}\left(\mathrm{~J} \mathrm{~mol}{ }^{-1} \mathrm{~K}^{-1}\right)$ & $142 \pm 2$ & & \\
${ }^{\text {app }} \mathrm{K}_{\mathrm{d} 2}$ & $1.1 \pm 0.210^{-5}$ & $8.5 \pm 4.910^{-6}$ & $1.010^{-8[\mathrm{a}]}$ \\
${ }^{\text {cond }} \mathrm{K}_{\mathrm{d} 2}$ & $5.3 \pm 1.010^{-9}$ & $2.5 \pm 1.410^{-8}$ & $1.010^{-8[\mathrm{a}]}$ \\
\hline
\end{tabular}

[a] Apparent dissociation $\left({ }^{a p p} K_{d}\right)$ constants used to fit the data obtained by ESI$\mathrm{MS}$ at $25^{\circ} \mathrm{C}$. Refer to Fig. 4 for more details.

In order to get insights onto the weaker binding site, ITC experiments were performed starting from a 1:1 CATm1: $\mathrm{Cu}(\mathrm{OAc})_{2}$ mixture. The stoichiometry extracted from the binding isotherm was about 0.25 (Figure $\mathrm{S} 8 \mathrm{C}$ to $\mathrm{E}$ ), thus indicating that the heat exchanges do not correspond to the complexation of the second copper ion. This suggests that at 1:1 CATm1:Cu(OAc) $)_{2}$ ratio, a mixture of complexes is already present in solution, and thus that the two binding sites have affinities too close to be distinguished in ITC. It has been recently shown that mass spectrometry can reliably and accurately provide both speciation and binding constants for noncovalent protein complexes and peptidyl or proteyl metal complexes. $^{66-69}$ Consequently, a titration by electrospray ionization mass spectrometry (ESI-MS) was performed in ammonium formate $(10 \mathrm{mM})$ at $\mathrm{pH} 7.5$ to obtain the relative binding constants. Upon addition of copper(II) acetate to a solution of CATm1 $(20 \mu \mathrm{M})$, complexes with two stoichiometries corresponding to CATm1:Cu 1:1 and 1:2 were identified. After each addition of $\mathrm{Cu}$ (II), the ESI-mass spectrum was measured. Representative spectra are given in Figure 4A. The relative abundances of CATm1, CATm1:Cu 1:1, and CATm1:Cu 1:2 were normalized at each step in the ESI-MS titration and the mole equivalents of $\mathrm{Cu}$ (II) bound were calculated from the mass spectra to generate the speciation as a function of $\mathrm{Cu}$ (II) added (Figure 4B). The speciation curves obtained were simulated using Hyperquad Simulation and Speciation (HySS) to afford the relative stepwise apparent dissociation constants for the first copper(II) $\left(\mathrm{K}_{\mathrm{d} 1}\right)$ and the second copper(II) $\left(\mathrm{K}_{\mathrm{d} 2}\right)$ bound to the peptide. The corresponding apparent dissociation constants used to fit the data in Figure 4 were in the range of $10^{-8}$ $10^{-9}$ with the first association constant being 4 times higher than the second. In the absence of a standard, the absolute values of these $\mathrm{K}_{\mathrm{d}}$ are not determined. The speciation curves obtained using $\mathrm{CuSO}_{4}$ instead of $\mathrm{Cu}(\mathrm{OAc})_{2}$ were fitted using these constants and matched perfectly, confirming the reproducibility of the relative binding constants from the normalized ESI-mass spectral data (Figure S11). In addition, it shows that the copper counter-ion does not influence the stability of the complexes. In order to determine the apparent values of 
these dissociation constants, titrations were performed by fluorescence spectroscopy in a MOPS which is a competitive buffer. Indeed, a clear quenching of tyrosine fluorescence was observed upon addition of copper acetate as it has been already observed for others peptides that bind copper(II). ${ }^{65}$ The titration curves were successfully fitted with a 1-to-2 ligandto-metal complex model using HypSpec software leading to apparent stepwise dissociation constants of $2.8 \pm 0.610^{-6}$ and $8.5 \pm 4.910^{-6}$ for the first and second site, respectively (Figure $\mathrm{S} 12$ ). $\mathrm{K}_{\mathrm{a} 1}$ is 3 times greater than $\mathrm{K}_{\mathrm{a} 2}$, which is consistent with the relative constants found by mass spectrometry. In addition, by considering the competition with MOPS, ${ }^{65}$ the conditional dissociation values fall in the $10^{-8}-10^{-9}$ range and are thus in line with the values used for the fits of the mass spectrometry data.

a)
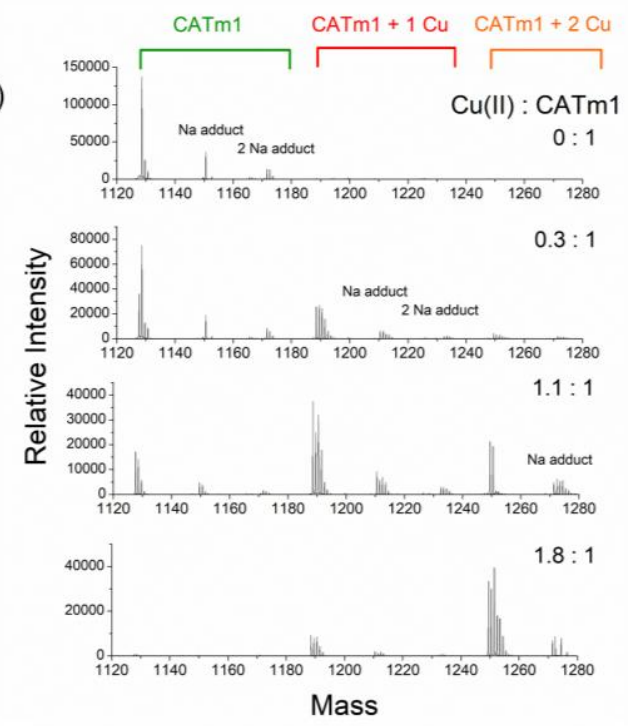

b)

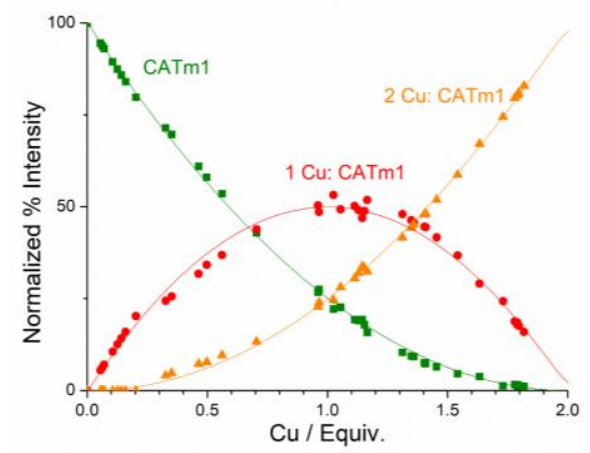

Figure 4. Titration of CATm1 $(20 \mu \mathrm{M})$ by copper acetate monitored by electrospray ionization mass spectrometry in ammonium formate $(10 \mathrm{mM})$ at $\mathrm{pH}$ 7.5. a) Representative normalized spectra at ratio CATm1:Cu(II) 1:0, 1:0.3, 1:1.1, 1:1.8 from top to bottom. b) Normalized abundance of each species calculated from the mass spectra during the titration. The experimental speciation was fitted by a simulated speciation using Hyperquad Simulation and Speciation (HySS) at the same concentration. From the simulated speciation, HySS provides relative cumulative $(\beta)$ binding constants for the first $\left(\beta_{1}\right)$ and second $\left(\beta_{2}\right) \mathrm{Cu}(\mathrm{II})$ binding to the peptide. From these cumulative binding constants, the relative stepwise binding constants $\left(\mathrm{K}_{\mathrm{A}}\right)$ for the first $\left(\mathrm{K}_{1}\right)$ and second $\left(\mathrm{K}_{2}\right) \mathrm{Cu}(\mathrm{II})$ bound to the peptide were determined with $\mathrm{K}_{1}$ being 4 times larger than $\mathrm{K}_{2}$, respectively. In the absence of a standard, the absolute values of $\mathrm{K}_{\mathrm{A}}$ were not determined.

Catalytic activity in solution
In order to determine the intrinsic catalase-like activity of the redox-active peptidyl complex derived from CATm1, $\mathrm{O}_{2}$ formation was monitored in solutions containing $\mathrm{H}_{2} \mathrm{O}_{2}$ and the catalyst. $\mathrm{O}_{2}$ was measured by polarography using a Clark-type electrode. $^{29}$ This was performed at $\mathrm{CATm} 1: \mathrm{Cu}(\mathrm{II})$ 1:2 ratio and with two copper salts $\left(\mathrm{CuO}(\mathrm{Ac})_{2}\right.$ and $\left.\mathrm{CuSO}_{4}\right)$ leading to apparent kinetic constants (Figure S13). The measurement of the initial rates $v_{0}=k_{\text {cat }}$ [catalyst $]_{0}\left[\mathrm{H}_{2} \mathrm{O}_{2}\right]_{0}$, which can be written $v_{0}=k_{\text {obs }}[\text { catalyst }]_{0}$ under pseudo first order conditions depending on the catalyst concentration, enabled the determination of $k_{\text {obs }}$ for $\mathrm{O}_{2}$ apparition. The measured $k_{\text {obs }}$ for the 1:2 peptide: $\mathrm{Cu}^{2+}$ ratio are higher than for the copper salts, which indicates that the peptidyl copper complex is a better catalyst than the copper salt for $\mathrm{H}_{2} \mathrm{O}_{2}$ dismutation (Table 2). The $\mathrm{O}_{2}$ formation reaction from $\mathrm{H}_{2} \mathrm{O}_{2}$ follows a Michaelis-Menten catalytic behavior, as does the natural enzyme. ${ }^{70}$ LineweaverBurk double reciprocal plot allows $k_{\text {cat }}$ and $\mathrm{K}_{\mathrm{M}}$ determination since the $\mathrm{x}$ intercept corresponds to $-1 / \mathrm{K}_{\mathrm{M}}$ and the slope to $\mathrm{K}_{\mathrm{M}} / \mathrm{V}_{\max }$ with $\mathrm{V}_{\max }=k_{\text {cat }}$ [catalyst $]_{0}$ (Figure S14). The measured $k_{\text {cat }}$ is for $\mathrm{O}_{2}$ evolution and thus corresponds to half of $k_{\text {cat }}$ of $\mathrm{H}_{2} \mathrm{O}_{2}$ dismutation (owing the stoichiometric coefficients in 2 $\mathrm{H}_{2} \mathrm{O}_{2} \rightarrow \mathrm{O}_{2}+2 \mathrm{H}_{2} \mathrm{O}$ ).

Table 2. Parameters describing the catalysis of $\mathrm{H}_{2} \mathrm{O}_{2}$ dismutation in MOPS (50 mM, pH 7.5, $\left.25^{\circ} \mathrm{C}\right)$.

\begin{tabular}{|c|c|c|c|c|c|}
\hline & $\begin{array}{c}k_{\mathrm{obs}}^{\text {[a] }} \\
\left(\mathrm{s}^{-1}\right)\end{array}$ & $\begin{array}{l}\mathrm{K}_{\mathrm{M}} \\
(\mathrm{M})\end{array}$ & $\begin{array}{c}k_{\text {cat }}^{[\mathrm{b}]} \\
\left(\mathrm{s}^{-1}\right) \\
\end{array}$ & $\begin{array}{l}k_{\mathrm{cat}} / \mathrm{K}_{\mathrm{M}}{ }^{[\mathrm{b}]} \\
\left(\mathrm{M}^{-1} \cdot \mathrm{s}^{-1}\right) \\
\end{array}$ & Ref. \\
\hline $\mathrm{CuSO}_{4}$ & $3.210^{-3}$ & & & & This work \\
\hline CATm1: $\mathrm{CuSO}_{4} 1: 2$ & $2.010^{-2}$ & $1.910^{-2}$ & $7.510^{-2}$ & 4.0 & This work \\
\hline $\mathrm{Cu}(\mathrm{OAc})_{2}$ & $7.410^{-3}$ & & & & This work \\
\hline $\mathrm{CATm} 1: \mathrm{Cu}(\mathrm{OAc})_{2} 1: 2$ & $1.310^{-2}$ & $2.110^{-2}$ & $1.210^{-1}$ & 5.5 & This work \\
\hline Catalase & $1.110^{3}$ & & & & This work \\
\hline $\mathrm{Cu}(\mathrm{N}-\mathrm{baa})_{2}(\text { phen })^{[\mathrm{c}]}$ & & $5.210^{-2}$ & $6.610^{-2}$ & 1.3 & 33 \\
\hline$[\mathrm{Cu}(\mathrm{HL})]\left(\mathrm{ClO}_{4}\right)_{2}{ }^{[\mathrm{d}]}$ & & $1.710^{1}$ & $1.510^{-3}$ & $8.910^{-5}$ & 35 \\
\hline $\mathrm{Cu}_{2}$ (pxdiprbtacn) $\mathrm{Cl}_{4}{ }^{[\mathrm{e}]}$ & & 1.5 & 1.24 & 0.8 & 40 \\
\hline Catalase & & $8.310^{-2}$ & $2.610^{5}$ & $3.110^{6}$ & 70 \\
\hline
\end{tabular}

T. thermophiles

[a] $k_{\text {obs }}$ are pseudo first order constant for $\mathrm{O}_{2}$ evolution measured with $\left[\mathrm{H}_{2} \mathrm{O}_{2}\right]=4.9 \mathrm{mM}$.

[b] $k_{\text {cat }}$ are first order rates for $\mathrm{H}_{2} \mathrm{O}_{2}$ dismutation and $\mathrm{K}_{\mathrm{M}}$ the MichaelisMenten constants. In this work, they have been measured with CATm1: $\mathrm{Cu}^{2+} 1: 2$ mixture at $100 \mu \mathrm{M}$.

[c] N-baaH: N-benzoylanthranilic acid, phen: 1,10-phenanthroline. The reactions were performed in DMF at $20^{\circ} \mathrm{C}$

[d] HL: 1,3-bis[(2-aminoethyl)amino]-2-propanol. The reactions were performed at $25^{\circ} \mathrm{C}$ in TRIS buffer, $\mathrm{pH} 7.2$.

[d] pxdiprbtacn:

1,4-Bis(4,7-diisopropyl-1,4,7-triazacyclonon-1-ylmethyl)benzene. The reactions were performed in phosphate buffer $(0.01 \mathrm{M}, \mathrm{pH}=7.4)$ at $25^{\circ} \mathrm{C}$.

The apparent second order constant $\left(k_{\mathrm{cat}} / \mathrm{K}_{\mathrm{M}}\right)$ for the 1:2 complexes are similar, whatever the copper salt used, and are higher than the values reported for other copper complexes and in particular for those measured in aqueous solutions, where it is more challenging to measure this activity (Table 2). However, the apparent second order constants of CATm1:Cu 1:2 complexes are much lower than those of purified natural catalase, showing that there is still room for improvement. Additionally, the turnover number (TON), the turnover frequency (TOF), and the maximum yield of $\mathrm{H}_{2} \mathrm{O}_{2}$ dismutation were calculated and are reported in Table S2 (SI). The TON is about 3 which is slightly weaker than for most manganese porphyrins but higher than for many other Mn complexes with CAT-like activities. ${ }^{29}$ During $\mathrm{O}_{2}$ monitoring by polarography, when $\mathrm{O}_{2}$ evolution reached a plateau, the dismutation of $\mathrm{H}_{2} \mathrm{O}_{2}$ could have been again fasten by the addition of fresh catalyst (Figure S15). This suggests that the catalyst was inactivated 
during the process, which in turn, may explain the low calculated TON. This has been confirmed by mass and UV-vis spectrometry experiments (Figure S16 and S17). By ESI mass spectrometry, upon addition of $\mathrm{H}_{2} \mathrm{O}_{2}$ (20 equivalents), catalyst oxidation and fragmentation were rapidly observed (Figure $\mathrm{S} 16$ ). UV-vis spectrometry enabled the determination of the pseudo first order rate of catalyst degradation, which was found one order of magnitude slower than pseudo first order rate of $\mathrm{H}_{2} \mathrm{O}_{2}$ dismutation (Figure $\mathrm{S} 17$ ). This clearly supports the fact that the catalyst can cycle several times before being inactivated. To note, as already reported, the 1:1 complex has been investigated for its SOD activity in cuvette using the McCord and Fridovich assay. ${ }^{43}$ In this assay, the $\mathrm{IC}_{50}$ of the 1:1 complex was $372 \mathrm{nM}$ which was only 1.6 time better than $\mathrm{CuSO}_{4}\left(\mathrm{IC}_{50}=603 \mathrm{nM}\right)$. This shows that this complex has a very weak SOD activity. This illustrates that the strategy allowed for the selection of an efficacious catalyst for the targeted activity only.

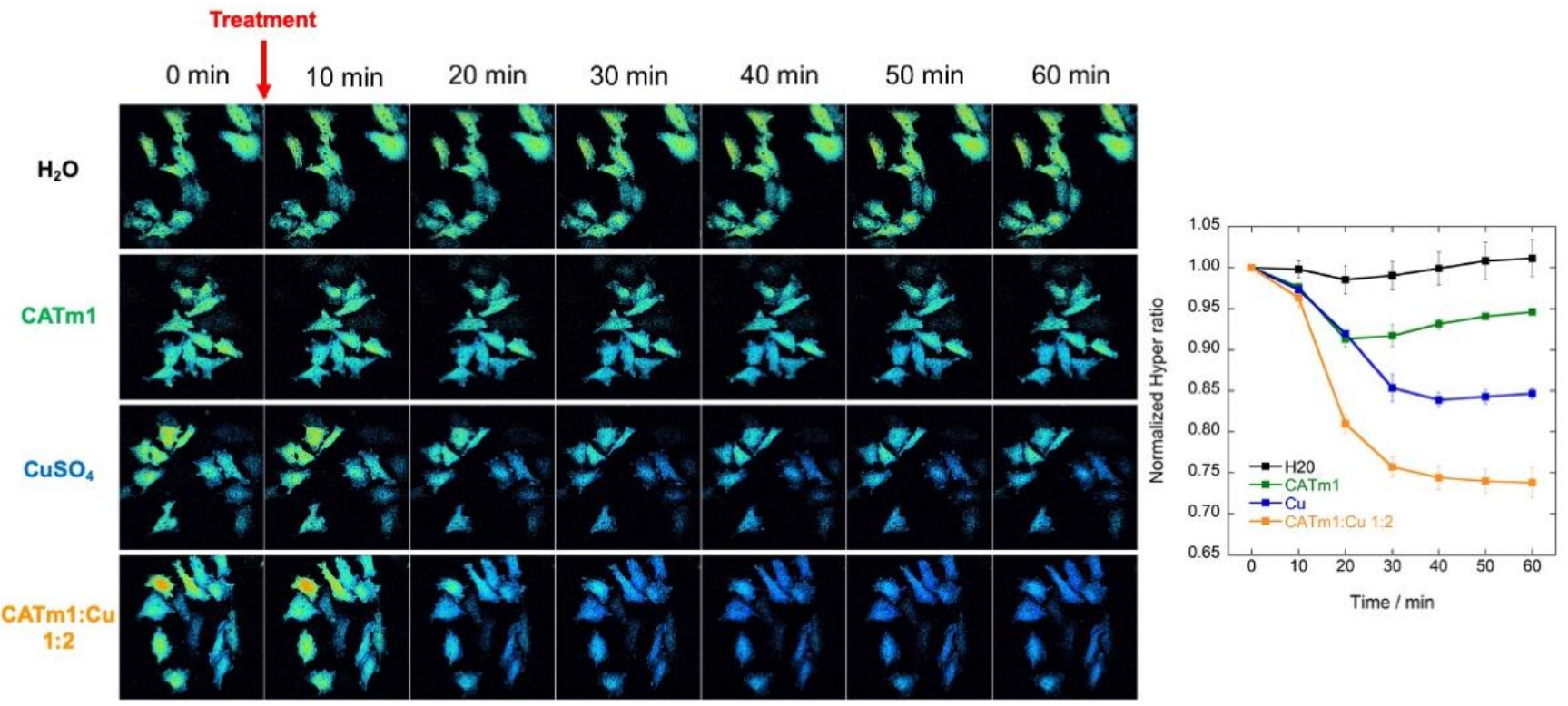

Figure 5. $\mathrm{H}_{2} \mathrm{O}_{2}$ levels in Hela Hyper cells monitored by fluorescence for 60 min after treatment with $\mathrm{H}_{2} \mathrm{O}$ (control cells), CATm1 peptide (250 $\mu \mathrm{M}$ ), CuSO $(500 \mu \mathrm{M})$, complex CATm1-Cu ${ }^{2+} 1: 2(250 \mu \mathrm{M})$. The right panel represents the mean of the ratio for 2 or 3 independent experiments.

\section{Catalytic activity in cells}

To go further, this new catalyst was assayed on HeLa cells which express the protein HyPer intracellularly. HyPer is a genetically encoded ratiometric fluorescent sensor of $\mathrm{H}_{2} \mathrm{O}_{2}$ based on a circularly permuted yellow fluorescent protein (cpYFP) integrated into the regulatory domain of the bacterial $\mathrm{H}_{2} \mathrm{O}_{2}$ sensing protein OxyR (OxyR-RD). ${ }^{71}$ In presence of $\mathrm{H}_{2} \mathrm{O}_{2}$, thiols of HyPer are oxidized, leading to the formation of disulfide bridges that modify the conformation of the protein and thus its spectral properties. The ratiometric modification of the excitation spectrum of HyPer can consequently allow monitoring $\mathrm{H}_{2} \mathrm{O}_{2}$ levels by measuring the ratio $\mathrm{I}_{(491 / 530) /} \mathrm{I}_{(405 / 530) .}{ }^{72-74}$ This ratio was monitored for $60 \mathrm{~min}$ for several cells (typically 10 to 25 cells) before and after addition of CATm1:Cu 1:2 mixture at $250 \mu \mathrm{M}$ and the corresponding controls (CATm1 at $250 \mu \mathrm{M}$, or $\mathrm{CuSO}_{4}$ at $\left.500 \mu \mathrm{M}\right)$ in MOPS buffer $\left(30 \mathrm{mM}, \mathrm{pH}\right.$ 7.5). To note, no additional $\mathrm{H}_{2} \mathrm{O}_{2}$ was added, the observed effects are thus modifications of the basal level of $\mathrm{H}_{2} \mathrm{O}_{2}$. Since $\mathrm{H}_{2} \mathrm{O}_{2}$ is mainly produced at the membranes and can easily diffuse through, ${ }^{75}$ an efficient catalase mimic that remains outside the cells may induce a decrease of the $\mathrm{H}_{2} \mathrm{O}_{2}$ concentration inside the cells. This is the case of HeLa HyPer cells incubated with catalase that does not translocate into cells but leads to a fluorescence ratio decrease. ${ }^{76}$ We have previously reported the use of Hyper Hela to quantify the activity of a range of Mn-based anti-oxidants. ${ }^{74}$ The intensity ratios $\left(\mathrm{I}_{(491 / 530)} / \mathrm{I}_{(405 / 530)}\right)$ normalized against the values from the cells before the addition of the tested compounds are reported in Figure 5. As shown in Figure 5, the $\mathrm{H}_{2} \mathrm{O}_{2}$ concentration decreased rapidly after addition of the 1:2 complex and was then stabilized around $28 \%$ after $40 \mathrm{~min}$. For the CATm1 peptide alone, a slight decrease of the fluorescence ratio was also observed, but after $20 \mathrm{~min}$ the $\mathrm{H}_{2} \mathrm{O}_{2}$ concentration increased to the initial level. Addition of $\mathrm{CuSO}_{4}$ led to a decrease of the $\mathrm{H}_{2} \mathrm{O}_{2}$ concentration, but only by $19 \%$. Significantly, these data strongly support the fact the 1:2 complex is efficacious for $\mathrm{H}_{2} \mathrm{O}_{2}$ dismutation in a cellular context.

In conclusion, this innovative strategy combining a combinatorial approach with an activity-based screening of the peptidyl metal complexes library led to the discovery of an efficacious di-Cu(II) complex with CAT activity. As far as we know, this is the first peptidyl complex mimicking the antioxidant properties of CAT reported so far. Its characterization was performed using a range of techniques (CD, ITC, CV, fluorescence and ESI-MS), and its activity was determined in solution using a Clark electrode and in a cellular assay. The cellular assay results are very encouraging as many potential metal ligands exist in the cell culture media that could have competed with the peptide and could have led to its destruction. The biological activity of this class of complexes may be improved if a higher stability could be achieved and work towards this goal is currently in progress in the lab.

\section{EXPERIMENTAL SECTION}

\section{General}

All chemicals and solvents were of synthesis grade and were used as received without further purification. Common solvents for solid support synthesis and L-amino acids were obtained from either Sigma Aldrich, Novabiochem or Iris biotech GMBH. CATm1 peptide was synthesized on an Advanced ChemTech automated synthesizer at the 
IBPS SU, FR3631 peptide synthesis core facility and purified by HPLC as described.

MALDI-TOF mass spectra were recorded on a Voyager DE-Pro MALDI-TOF mass spectrometer (Applied Biosystems) in positive mode using as matrix a solution of $\alpha$-Cyano-4-hydroxycinnamic acid (CHCA) at $10 \mathrm{mg} / \mathrm{mL}$ in $\mathrm{CH}_{3} \mathrm{CN}: \mathrm{H}_{2} \mathrm{O}(50: 50)$ containing $0.1 \%$ TFA. Calibration was performed using external standards (Proteomix 4, LaserBio Labs Sofia-Antipolis, France). Electrospray ionization mass spectrometry was performed on a Bruker MicrOTOF II with the following parameters: capillary voltage $=4200 \mathrm{~V}$, Nebulizer $=2.0 \mathrm{Bar}$, Dry gas $=4.0 \mathrm{~L} / \mathrm{min}$, Dry Temp $=200{ }^{\circ} \mathrm{C}$, Capillary exit voltage $=$ $100 \mathrm{~V}$. Analytical HPLC was performed on an Agilent Technologies 1200 Series equipped with a multiple wavelength absorbance detector, using a Proto $200 \mathrm{C} 183 \mu \mathrm{m}$ Higgins Analytical Inc. $100 \times 4.6$ $\mathrm{mm}$ column. Preparative HPLC was performed on a Waters 600 HPLC Pump equipped with a Waters 2487 dual wavelength absorbance detector, using a Column VP 260/16 C18 Htec $5 \mu \mathrm{m}$. UV-vis spectrometry was performed on a Cary 300 bio in a double beam mode with the buffer in the reference cell at $25^{\circ} \mathrm{C}$. Electron Paramagnetic Resonance (EPR) data were recorded using an Elexsys E500 Bruker spectrometer, operating at a microwave frequency of approximately $9.44 \mathrm{GHz}$. Spectra were recorded using a microwave power of $20 \mathrm{~mW}$ across a sweep width of $250 \mathrm{mT}$ (centered at $310 \mathrm{mT}$ ) with modulation amplitude of $0.5 \mathrm{mT}$. Experiments were carried out at 110 $\mathrm{K}$ using a liquid nitrogen cryostat. Circular dichroism (CD) spectra $(215-300 \mathrm{~nm})$ were collected on a J-810 spectropolarimeter (Jasco, Tokyo, Japan). Cyclic Voltammetry measurement were performed using a MetrOhm potentiostat (AUTOLAB model). All measurements were carried out in the indicated buffer. Glassy carbon (GC), a platinum plate and SCE $\mathrm{KCl}$ saturated were used as working electrode, counter and reference electrode, respectively; all potential values are reported versus NHE reference. Isothermal titration calorimetry (ITC) experiments were performed on a TA Instrument (New Castle, DE) NanoITC calorimeter and analyzed using the provided software. The ability of the complex to catalyze $\mathrm{H}_{2} \mathrm{O}_{2}$ dismutation was measured by polarography. Titrations by fluorescence were performed on a Jasco FP-8300 spectrofluorimeter. $\mathrm{An}_{2}$-sensitive Clark-type electrode OD InLab 605-ISM purchased from Mettler Toledo was used. Prior to measurements, the electrode was calibrated in ambient air then in a provided $0 \%$ dissolved oxygen solution.

Procedures and data analysis

Peptide library synthesis on solid support (Figure S1)

Linkers coupling and first amino acid grafting. The peptides library was synthesized manually on solid support by using standard Fmoc chemistry on 1 gram of Tentagel macrobeads (loading: 0.24 $\mathrm{mmol} / \mathrm{g}, 280-300 \mu \mathrm{m})$. First, orthogonal linkers (6 equiv.) coupling was performed on a solution of HMBA and 3-N-Fmoc-amino-3-(2nitrophenyl)propionic acid (Fmoc - ANP) linkers (10:1) with HOBT ( 1 equiv.) and DIC ( 1 equiv.) in DMF for $1 \mathrm{~h}$. Standard deprotection conditions of Fmoc group were employed (20\% piperidine in DMF for $1 \mathrm{~min}$ then $10 \mathrm{~min}$ at room temperature) followed by washings with NMP. Then the first amino acid was introduced by treatment with the symmetrical anhydride of BAla (6 equiv.) in the presence of 4-dimethylaminopyridine ( 0.1 equiv.) in DMF for $1 \mathrm{~h}$.

Amino acid coupling reactions (without capping). Coupling reactions were performed in NMP ( $3 \mathrm{~mL})$ with HOBT (3 equiv.) and HBTU (3 equiv.) as coupling agents and in basic conditions (diisopropylethylamine, DIEA, 6 equiv.). The resin was shaken for 45 to $60 \mathrm{~min}$ at room temperature. After each reaction, solvents and soluble reagents were removed under vacuum and the resin was washed 5 times with NMP. Completion of the reaction was monitored by the Kaiser test, which indicates the presence of free amine by a blue coloration of the bead. The amino acid coupling was repeated as many times as necessary until a negative test Kaiser was obtained. Then, Standard deprotection conditions of Fmoc group were employed (20\% piperidine in DMF for $1 \mathrm{~min}$ then $10 \mathrm{~min}$ at room temperature) followed by washings with NMP $(5 \times 3 \mathrm{~mL})$.

Amino acid coupling reactions (with capping). By using Bibilo software, the positions in the library that required capping were identified, then manual calculation of truncated peptide molar mass allowed for the determination of which commercially available capping reagent combination was required to obtain a non-degenerate mass ladder. The twelfth coupling required simultaneous capping since it is a mass encoding step. Coupling then involved treatment with a mixture of the desired amino acid and mass cap (85:15, 10 equiv.), N,N diisopropylcarbodiimide (DIC), and N-hydroxybenotriazole (HOBt) in 10:10 ratio in DMF for 1 hour. The mass caps were: BocD for E, BocW for H, BocF for Y, BocI for R and BocA for G.

Split and pool strategy. The ninth, twelfth and the thirteenth coupling were performed after splitting the resin. The resin was split into 5 approximately equal portions. Then, each batch reacted with a different amino acid using standard coupling conditions. After the reaction, all five batches were pooled together and the next coupling was performed.

A final acetylation was performed on the last amino acid (Proline) by a solution of acetic anhydride in dichloromethane (DCM) $(3 \mathrm{~mL}$ $10 / 90 \mathrm{v}: \mathrm{v})$ for $1 \mathrm{~h}$ at room temperature. Solvents and soluble reagents were removed by filtration. The resin was washed with DCM $(5 \times 3$ $\mathrm{mL})$ then by methanol $(3 \times 3 \mathrm{~mL})$. The resin was dried under vacuum for $1 \mathrm{~h}$. Finally, deprotection of the lateral chains was carried out in acidic conditions with TFA/ $\mathrm{H}_{2} \mathrm{O} /$ Trisopropylsilane $(95 \% / 2.5 \% / 2.5 \%)$ for $2 \mathrm{~h}$ at room temperature. The resin was then washed sequentially by TFA, DCM and HEPES buffer.

\section{Complexes formation}

Beads (ca. $50 \mathrm{mg}$ ) were inserted in PP syringe with a frit and were washed with HEPES $(50 \mathrm{mM}, \mathrm{pH} 7.5)$ solution $(3 \times 1 \mathrm{~mL})$. The beads were incubated for $2 \mathrm{~h}$ at $60^{\circ} \mathrm{C}$ with $2 \mathrm{~mL}$ of a $\mathrm{Cu}(\mathrm{OAc})_{2}$ solution $(10$ $\mathrm{mM})$ in HEPES $(50 \mathrm{mM}, \mathrm{pH} 7.5)$. After incubation, the solution was removed by filtration and the beads were washed with HEPES (50 $\mathrm{mM}$, pH 7.5, $1 \times 1 \mathrm{~mL})$, EDTA $(25 \mathrm{mM}, 1 \mathrm{~min}, 1 \times 1 \mathrm{~mL})$ then again with HEPES $(50 \mathrm{mM}, \mathrm{pH} 7.5,3 \times 1 \mathrm{~mL})$ solution to increase the selectivity pressure.

\section{Combinatorial screening and selection}

The beads (approximatively 50-100) were introduced in a small beaker and molten agarose $(10 \mathrm{~mL}, 2 \%$ in HEPES $50 \mathrm{mM}, \mathrm{pH} 7.5)$ was added. The solution was poured into a Petri dish, so that the beads were evenly distributed in the dish. The solution was kept at room temperature for 10 minutes to allow the formation of a gel. The agarose gel was then placed under a UV lamp (electronic dual light transilluminator) at $254 \mathrm{~nm}$ during $10-15 \mathrm{~min}$ to cleave the photocleavable linker. The gel was then incubated with a $\mathrm{H}_{2} \mathrm{O}_{2}$ solution $(10 \mathrm{~mL}, 0.015 \%, 10 \mathrm{~min})$ then rinsed extensively with $\mathrm{H}_{2} \mathrm{O}$ milliQ. The water was poured off. $\mathrm{A} 2 \% \mathrm{FeCl}_{3}$ solution $(0.6 \mathrm{mg}$ in 30 $\mathrm{mL} \mathrm{H}_{2} \mathrm{O}$ milliQ) and a $2 \%$ potassium ferricyanide solution $(0.6 \mathrm{mg}$ in $30 \mathrm{~mL} \mathrm{H}_{2} \mathrm{O}$ milliQ) were poured together directly on top of the gel. The solution became blue and the gel was incubated for 3 minutes then extensively washed by $\mathrm{H}_{2} \mathrm{O}$ milliQ. Beads with white halos were cut from the agarose gel with a tip of a $1 \mathrm{~mL}$ pipette and transferred to a $1.5 \mathrm{~mL}$ eppendorf tube. The residual agarose surrounding the selected bead was melted away in distilled $\mathrm{H}_{2} \mathrm{O}(1 \mathrm{~mL})$ at $110^{\circ} \mathrm{C}$. The selected bead was subsequently washed with ethylenediaminetetraacetate $(0.5 \mathrm{M}$; pH 7.0$)$, then extensively with $\mathrm{H}_{2} \mathrm{O}$ for the metal decoordination. Peptides were cleaved from the bead by treatment with $\mathrm{NH}_{4} \mathrm{OH}(28 \%, 50 \mu \mathrm{L})$ overnight at room temperature. After cleavage, the solution was freeze-dried, and the peptide residue resuspended in an $\mathrm{H}_{2} \mathrm{O}$ milliQ $(100 \mu \mathrm{L})$ as a library stock solution.

\section{Sequence determination by MALDI-TOF mass spectrometry}

$1 \mu \mathrm{L}$ of peptide stock solutions was mixed with $1 \mu \mathrm{L}$ of matrix solution and $1 \mu \mathrm{L}$ of the mixture solution was placed onto the MALDI plate and allowed to crystallize. Peptides sequencing was carried out with the Software developed by C. Griesinger et al. ${ }^{53}$ ( Figure S4).

\section{CATm1 purification}

The peptide was purified by reverse phase HPLC on a VP260/16 semipreparative column with a linear gradient from 5 to $30 \%$ acetonitrile in water both containing $0.1 \%$ TFA over $30 \mathrm{~min}$. High purity (> 95\%) was confirmed by analytical HPLC (Proto 200 C18 column from $5 \%$ to $100 \%$ acetonitrile in water and $0.1 \%$ TFA over $10 \mathrm{~min}$ ) and the expected mass was found by MALDI-TOF mass spectrometry: $[\mathrm{M}+\mathrm{H}]^{+}=1128.4$ (Figure S2 and S3).

Peptide stock solution preparation 
Stock solution of the peptide was prepared by dissolving peptide powder in milliQ water. Stock solution concentration was determined by measuring the UV-vis spectrum of a diluted solution $(1 \mu 1$ in 449 $\mu \mathrm{l}$ of milliQ water) and using the extinction coefficient of the tyrosine Tyr considered as free tyrosine $\left(\varepsilon_{276}=1280 \mathrm{~cm}^{-1} \mathrm{M}^{-1}\right)$.

\section{Electron Paramagnetic Resonance spectroscopy (EPR)}

EPR experiments were carried out at $110 \mathrm{~K}$ using liquid nitrogen cryostat. EPR samples $(200 \mu \mathrm{l})$ were prepared from stock solution of peptide diluted down to $0.2 \mathrm{mM}$ in MOPS buffer ( $0.5 \mathrm{M}, \mathrm{pH} 7.5)$. $\mathrm{Cu}^{2+}$ was added from $50 \mathrm{mM}$ stock solution of $\mathrm{CuSO}_{4}$ in water to form the complexes. Samples were frozen in an ethanol/liquid nitrogen solution in quartz tube after addition of $10 \%$ glycerol as a cryoprotectant and stored in liquid nitrogen until used.

\section{Titration by circular dichroism (CD)}

Spectra of solutions of Catm1 $(200 \mu \mathrm{M})$ in MOPS buffer $(50 \mathrm{mM}, \mathrm{pH}$ 7.5) were recorded before and after successive additions of $\mathrm{CuSO}_{4}$. A $1 \mathrm{~mm}$ cell was used and the spectra were recorded with a Peltier temperature controller set at $298 \mathrm{~K}$ under constant nitrogen flush. The wavelength range was set from $300 \mathrm{~nm}$ to $215 \mathrm{~nm}$. The scan rate, the sensitivity, and bandwidth were respectively $200 \mathrm{~nm} \cdot \mathrm{min}^{-1}, 0.125 \mathrm{~s}$, and $1 \mathrm{~nm}$. Each spectrum was an average of three scans.

Cyclic voltammetry experiments

All measurements were carried out in a buffer (MOPS or TRIS at $\mathrm{pH}$ 7.5 or 7). Glassy carbon (GC), a platinum plate and SCE $\mathrm{KCl}$ saturated were used as the working electrode, counter and reference electrode, respectively. All potential values are reported versus the SCE reference electrode. Dissolved dioxygen was removed by bubbling the solution with dinitrogen gas. Between each measurement the working electrode was washed with distilled water and polished with sand paper.

\section{Isothermal titration calorimetry (ITC)}

Titration at $\mathbf{p H}$ 7: titrations were performed by injecting $10 \mu \mathrm{L}$ aliquots of $5 \mathrm{mM} \mathrm{Cu}(\mathrm{OAc})_{2}$ in MOPS buffer $(50 \mathrm{mM}$; pH 7) into the calorimeter cell containing the peptide CATm1 solution (ca $0.5 \mathrm{mM}$ ) diluted in MOPS buffer (50 mM; pH 7), with 5 min between two injections. The experiments were performed at $25{ }^{\circ} \mathrm{C}$. Data were analyzed using the program NanoAnalyze provided by TA Instruments.

Titration at pH 7.5: titrations were performed by injecting $10 \mu \mathrm{L}$ aliquots of $5 \mathrm{mM}$ or $10 \mathrm{mM} \mathrm{Cu}(\mathrm{OAc})_{2}$ in MOPS buffer $(50 \mathrm{mM}$; pH 7.5) into the calorimeter cell containing the peptide CATm1 solution (ca $0.5 \mathrm{mM}$ ) or 1:1 CATm1:Cu(OAc) 2 mixture (at 1 or $2 \mathrm{mM}$ ) diluted in MOPS buffer ( $50 \mathrm{mM}$; $\mathrm{pH} 7$ ), with $5 \mathrm{~min}$ or $10 \mathrm{~min}$ between two injections. The experiments were performed at $25{ }^{\circ} \mathrm{C}$. Data were analyzed using the program NanoAnalyze provided by TA Instruments. (See SI for more details).

\section{Titration by electrospray ionization mass spectrometry}

$1 \mathrm{mM} \mathrm{Cu}(\mathrm{OAc})_{2} \bullet \mathrm{H}_{2} \mathrm{O}$ was titrated into $20 \mu \mathrm{M} \mathrm{CATm} 1$ peptide solution in a $10 \mathrm{mM}$ ammonium formate solution at $\mathrm{pH}$ 7.5. After each addition of $\mathrm{Cu}$ (II), the sample was measured using electrospray ionization mass spectrometry. The abundance of apo CATm1, CATm1$\mathrm{Cu}_{1}$, and CATm1- $\mathrm{Cu}_{2}$ were normalized from each step in the ESI-MS titration. The amount of $\mathrm{Cu}$ (II) bound was calculated from the mass spectra to generate the speciation as a function of $\mathrm{Cu}(\mathrm{II})$ added. This speciation was simulated using Hyperquad Simulation and Speciation (HySS). The same concentrations of peptide and $\mathrm{Cu}(\mathrm{II})$ as the experimental data were used in the HySS simulation. 2.0 mol. eq. of $\mathrm{Cu}$ (II) were added in the simulated titration. HySS uses cumulative $(\beta)$ binding constants and the simulated cumulative constant for the first $\left(\beta_{1}\right)$ and second $\left(\beta_{2}\right) \mathrm{Cu}(\mathrm{II})$ binding to the peptide were adjusted until the simulation fit the experimental data. From these cumulative binding constants, the stepwise binding constants for the first $\left(\mathrm{K}_{1}\right)$ and second $\left(\mathrm{K}_{2}\right) \mathrm{Cu}(\mathrm{II})$ bound to the peptide were found to be $10^{8.6}$ and $10^{8}$, respectively. ESI-mass spectral data have been reported to accurately represent the speciation following metal binding into various protein systems. ${ }^{68,69,77,78}$ It appears that the binding of metals typically does not impart significant differences in the ionization efficiency which allows for the quantitation of the species present. With respect to the results presented in this paper, the binding constants were calculated from a simulation of the data in Figure 4. These same binding constants were used to fit the results of a separate titration where $5 \mathrm{mM} \mathrm{CuSO}_{4}$ was titrated into $20 \mu \mathrm{M} \mathrm{CATm} 1$ in $0.5 \mathrm{mM}$ ammonium formate buffer at $\mathrm{pH} 7.56$. The quality of the fit shown in Figure S11 is essentially identical to the fit shown in Figure 4, confirming the reproducibility of the binding constants from the normalized ESI-mass spectral data. In addition, the amount of copper bound to the peptide can be determined from the ESI-mass spectral data and this compared to the mol. equivalences of $\mathrm{Cu}$ (II) added to the solution (Figure S9). The ratio of $\mathrm{Cu}$ (II) added to $\mathrm{Cu}$ (II) recovered is nearly $1: 1$ indicating that the CATm1 speciation obtained by ESI-MS is representative of the solution speciation.

Titration by fluorescence spectrometry.

$\mathrm{Cu}(\mathrm{OAc})_{2} \bullet \mathrm{H}_{2} \mathrm{O}$ was titrated into CATm1 peptide solution in a $50 \mathrm{mM}$ MOPS buffer at $\mathrm{pH} 7.5$ at $25{ }^{\circ} \mathrm{C}$. After each addition of $\mathrm{Cu}(\mathrm{II})$, the emission spectrum (average of 2 accumulations) upon excitation at $275 \mathrm{~nm}$ was recorded between 280 and $400 \mathrm{~nm}$ (slit $_{\mathrm{exc}}=\mathrm{slit}_{\mathrm{em}}=5 \mathrm{~nm}$, scan rate $=200 \mathrm{~nm} / \mathrm{min}$ ). Before recording each spectrum, it was ensured that the thermodynamic equilibrium was reached (stable fluorescence intensity). The intensity at the maximum of tyrosine emission $(303 \mathrm{~nm})$ was used to generate the titration curves which were then fitted using HypSpec software. HypSpec determines cumulative $(\beta)$ binding constants for the first $\left(\beta_{1}\right)$ and second $\left(\beta_{2}\right) \mathrm{Cu}(\mathrm{II})$ binding to the peptide. From these cumulative binding constants, the stepwise binding constants for the first $\left(\mathrm{K}_{1}\right)$ and second $\left(\mathrm{K}_{2}\right) \mathrm{Cu}(\mathrm{II})$ bound to the peptide were found. The provided $\mathrm{K}_{\mathrm{d}}$ values are the average of three independent titrations \pm standard error of the mean (SEM).

Catalase activity assay using a Clark-type electrode

The experiments were carried out in MOPS buffer $(50 \mathrm{mM}, \mathrm{pH} 7.5)$ at $25^{\circ} \mathrm{C}$ in a micro cell sealed with a rubber septum to avoid the introduction of $\mathrm{O}_{2}$ from the air. The dissolved dioxygen was removed by bubbling the solution with dinitrogen gas. Hydrogen peroxide solution $(15 \%, 1 \mu \mathrm{l})$ was added. The dioxygen from the spontaneous dismutation of hydrogen peroxide was removed by bubbling the solution with dinitrogen gas. Finally, sample was injected through the septum to the stirred $\mathrm{H}_{2} \mathrm{O}_{2}$ solution. Reaction rates were determined by measurement of the $\mathrm{O}_{2}$ evolved upon time as described in reference. ${ }^{29}$ The initial rates $v_{0}$ were measured from the slope of linear fits (from 0 to $20 \mathrm{~s}$ ) of dioxygen formation at several complex concentrations. Then $k_{o b s}$ corresponds to the slope of the linear fit of $v_{0}=$ $\mathrm{f}$ [catalyst] (Figure S11). The $\mathrm{O}_{2}$ formation reaction from $\mathrm{H}_{2} \mathrm{O}_{2}$ follows a Michaelis-Menten catalytic behavior similar to the natural enzyme. Michaelis-Menten constants $K_{\mathrm{m}}, \mathrm{V}_{\max }$ and $k_{\text {cat }}$ were determined using the Lineweaver-Burk double reciprocal plot: $1 / v_{0}=\mathrm{f}\left(1 /\left[\mathrm{H}_{2} \mathrm{O}_{2}\right]\right)$ for which the $\mathrm{x}$ intercept corresponds to $-1 / K_{\mathrm{m}}$, the slope to $K_{\mathrm{m}} / \mathrm{V}_{\max }$ and $\mathrm{V}_{\max }=k_{\text {cat O2 }}$ [catalyst $]_{0}$. Since during dismutation two $\mathrm{H}_{2} \mathrm{O}_{2}$ lead to the formation of a single $\mathrm{O}_{2}$ molecule $k_{\text {cat }}=2 \times k_{\text {cat } \mathrm{O} 2}$. To generate these plots, the initial rates at a catalyst concentration of $100 \mu \mathrm{M}$ were measured at several $\left[\mathrm{H}_{2} \mathrm{O}_{2}\right]$ concentrations (Figure S12). Complementary kinetics parameters were determined at $100 \mu \mathrm{M}$ of the catalysts in $4.9 \mathrm{mM} \mathrm{H}_{2} \mathrm{O}_{2}$ solution in MOPS $(50 \mathrm{mM})$ at $\mathrm{pH} 7.5$ (Table S2). The maximal yield of $\mathrm{O}_{2}$ production (in $\%$ ) was calculated from the measured $\left[\mathrm{O}_{2}\right]_{\max }$ obs values using the following equation: Yield $\mathrm{O}_{2}(\%)=$ $\left(2\left[\mathrm{O}_{2}\right]_{\max }\right.$ obs $\left./\left[\mathrm{H}_{2} \mathrm{O}_{2}\right]_{0}\right) \times 100$. The TON was calculated as maximal number of $\mathrm{O}_{2}$ moles produced per mole of a catalyst, $\mathrm{TON}=\left[\mathrm{O}_{2}\right]_{\max }$ obs / [Catalyst $]_{0}$. The TOF values in $\mathrm{s}^{-1}$ which represent the ratio of initial rates and concentrations of catalysts were calculated as followed: $\mathrm{TOF}=v_{0} /[\text { Catalyst }]_{0}$.

\section{Experiments on HeLa HyPer cells}

Cell culture. Stable cell line HeLa HyPer1 was prepared using the HeLa Flp-In cell line, which was kindly provided by Stephen Taylor ${ }^{79}$ and cultured at $37^{\circ} \mathrm{C}$ under a $5 \% \mathrm{CO}_{2}$ atmosphere. HyPer1 expression in this stable cell line was controlled by doxycycline, added $24 \mathrm{~h}$ after seeding. The cells were cultured for an additional $24 \mathrm{~h}$ before being processed for analysis.

Pharmacological treatments. Cells were incubated with or without antioxidant during $1 \mathrm{hr}$ at $37^{\circ} \mathrm{C}$ under a 5\% CO2 atmosphere.

Imaging. Imaging was performed with a CSU-W1 Yokogawa spinning disk coupled to a Zeiss Axio Observer Z1 inverted microscope equipped with a sCMOS Hamamatsu camera and a $63 \times$ objective (63×/1.4 oil WD: $0.17 \mathrm{~mm}$ ) oil objective. DPSS $100 \mathrm{~mW} 405 \mathrm{~nm}$ and 
$150 \mathrm{~mW} 491 \mathrm{~nm}$ lasers and a 525/50 bandpass emission filter were used.

$\mathrm{H}_{2} \mathrm{O}_{2}$ levels quantification and statistical analysis. Images were processed with the Fiji software, to obtain the HyPer1 ratio of the emission at $530 \mathrm{~nm}(491 / 530) /(405 / 530)$. HyPer ratio was then measured for several cells, and normalized to the ratio value of the control condition. Data were analyzed using GraphPad Prism 8 and expressed as the mean \pm standard error of the mean (SEM). Statistical significance was calculated using an ordinary one-way ANOVA followed by Tukey's multiple comparison test.

\section{ASSOCIATED CONTENT}

\section{Supporting Information}

The Supporting Information is available free of charge on the ACS Publications website.

Supplementary Scheme, figures, and tables, detailed experimental procedures, MALDI-TOF spectra, ITC thermograms, HPLC chromatograms, fluorescence images are provided.

\section{AUTHOR INFORMATION}

\section{Corresponding Author}

* nicolas.delsuc@ens.psl.eu

\section{Author Contributions}

All authors have given approval to the final version of the manuscript.

\section{Funding Sources}

This work was funded by the ANR JCJC MetalloPepZyme ANR16-CE07-0025. We acknowledge funding from National Sciences and Engineering Research Council (NSERC) of Canada through a Discovery Grant (2020-06545), USRA and CGS-M (AM). Work was also funded by NSERC of Canada through Discovery Grant 2020-06545 to M. J. S. and a Canada Graduate Scholarship to A. M. as well as by a Graduate Entrance Scholarship funded by the University of Western Ontario (A. M.). We also thank the University of Western Ontario for a collaborative Research Catalyst grant (M. J. S., A. M.).

\section{Notes}

The authors declare no competing financial interest.

\section{ACKNOWLEDGMENT}

The authors thank Carole Aimé (and the LCMCP), Sandrine Sagan et Sonia Lajnef for their help with the circular dichroism, Isothermal Titration Calorimetry and Electron Paramagnetic Resonance experiments respectively. We thank the IBPS SU, FR3631 mass spectrometry and peptide synthesis core facilities for access to the MALDI-TOF spectrometer and for providing us peptides respectively. Frédéric Lemaître and Manon Guille are gratefully acknowledged for their help with the electrochemistry experiments.

\section{REFERENCES}

(1) Dröge, W. Free Radicals in the Physiological Control of Cell Function. Physiological Reviews 2002, $82 \quad$ (1), 47-95. https://doi.org/10.1152/physrev.00018.2001.

(2) Holmström, K. M.; Finkel, T. Cellular Mechanisms and Physiological Consequences of Redox-Dependent Signalling. Nat Rev Mol Cell Biol 2014, 15 (6), 411-421. https://doi.org/10.1038/nrm3801.
(3) Sies, H.; Jones, D. P. Reactive Oxygen Species (ROS) as Pleiotropic Physiological Signalling Agents. Nat Rev Mol Cell Biol 2020, 21, 363-383. https://doi.org/10.1038/s41580-020-0230-3.

(4) Tönnies, E.; Trushina, E. Oxidative Stress, Synaptic Dysfunction, and Alzheimer's Disease. JAD 2017, 57 (4), 1105-1121. https://doi.org/10.3233/JAD-161088.

(5) Choudhury, G.; MacNee, W. Role of Inflammation and Oxidative Stress in the Pathology of Ageing in COPD: Potential Therapeutic Interventions. COPD: Journal of Chronic Obstructive Pulmonary Disease 2017, 14 (1), 122-135. https://doi.org/10.1080/15412555.2016.1214948.

(6) Murray, C. J.; Lopez, A. D. Alternative Projections of Mortality and Disability by Cause 1990-2020: Global Burden of Disease Study. The Lancet 1997, 349 (9064), 1498-1504. https://doi.org/10.1016/S01406736(96)07492-2.

(7) Cachofeiro, V.; Goicochea, M.; de Vinuesa, S. G.; Oubiña, P.; Lahera, V.; Luño, J. Oxidative Stress and Inflammation, a Link between Chronic Kidney Disease and Cardiovascular Disease. Kidney International 2008, 74, S4-S9. https://doi.org/10.1038/ki.2008.516.

(8) Bashan, N.; Kovsan, J.; Kachko, I.; Ovadia, H.; Rudich, A Positive and Negative Regulation of Insulin Signaling by Reactive Oxygen and Nitrogen Species. Physiological Reviews 2009, 89 (1), 27-71. https://doi.org/10.1152/physrev.00014.2008.

(9) Federico, A.; Morgillo, F.; Tuccillo, C.; Ciardiello, F.; Loguercio, C. Chronic Inflammation and Oxidative Stress in Human Carcinogenesis. Int. J. Cancer 2007, 121 (11), 2381-2386. https://doi.org/10.1002/ijc.23192.

(10) Crapo, J. D.; Oury, T.; Rabouille, C.; Slot, J. W.; Chang, L. Y. Copper,Zinc Superoxide Dismutase Is Primarily a Cytosolic Protein in Human Cells. Proceedings of the National Academy of Sciences 1992, 89 (21), 10405-10409. https://doi.org/10.1073/pnas.89.21.10405.

(11) Keller, G. A.; Warner, T. G.; Steimer, K. S.; Hallewell, R. A. $\mathrm{Cu}, \mathrm{Zn}$ Superoxide Dismutase Is a Peroxisomal Enzyme in Human Fibroblasts and Hepatoma Cells. Proceedings of the National Academy of $\begin{array}{lllll}\text { Sciences } & 1991, & 88 & \text { (16), }\end{array}$ https://doi.org/10.1073/pnas.88.16.7381.

(12) Liou, W.; Chang, L.; Geuze, H.; Strous, G.; Crapo, J.; Slot, J. Distribution of CuZn Superoxide Dismutase in Rat Liver. Free Radical Biology and Medicine 1993, 14 (2), 201-207. https://doi.org/10.1016/0891-5849(93)90011-I.

(13) Chang, L. Y. Molecular Immunocytochemistry of the CuZn Superoxide Dismutase in Rat Hepatocytes. The Journal of Cell Biology 1988, 107 (6), 2169-2179. https://doi.org/10.1083/jcb.107.6.2169.

(14) Barondeau, D. P.; Kassmann, C. J.; Bruns, C. K.; Tainer, J. A.; Getzoff, E. D. Nickel Superoxide Dismutase Structure and Mechanism ${ }^{\dagger}$. $\begin{array}{llll}\text { Biochemistry } & \text { 2004, } & 43 & \text { (25), }\end{array}$ https://doi.org/10.1021/bi0496081.

(15) Beauchamp, C.; Fridovich, I. Superoxide Dismutase: Improved Assays and an Assay Applicable to Acrylamide Gels. Analytical Biochemistry 1971, 44 (1), 276-287. https://doi.org/10.1016/0003-2697(71)903708 .

(16) Domínguez, L.; Sosa-Peinado, A.; Hansberg, W. Catalase Evolved to Concentrate $\mathrm{H} 2 \mathrm{O} 2$ at Its Active Site. Archives of Biochemistry

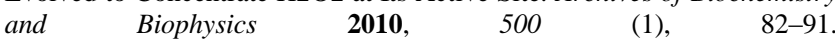
https://doi.org/10.1016/j.abb.2010.05.017.

(17) Obinger, C. Catalases and Hydrogen Peroxide Metabolism. Archives of Biochemistry and Biophysics 2012, 525 (2), 93-94. https://doi.org/10.1016/j.abb.2012.07.005.

(18) Brigelius-Flohé, R.; Maiorino, M. Glutathione Peroxidases Biochimica et Biophysica Acta (BBA) - General Subjects 2013, 1830 (5), 
3289-3303. https://doi.org/10.1016/j.bbagen.2012.11.020.

(19) Tosatto, S. C. E.; Bosello, V.; Fogolari, F.; Mauri, P.; Roveri, A.; Toppo, S.; Flohé, L.; Ursini, F.; Maiorino, M. The Catalytic Site of Glutathione Peroxidases. Antioxidants \& Redox Signaling 2008, 10 (9), 1515-1526. https://doi.org/10.1089/ars.2008.2055.

(20) Whittaker, J. W. Non-Heme Manganese Catalase - The 'Other' Catalase. Archives of Biochemistry and Biophysics 2012, 525 (2), 111120. https://doi.org/10.1016/j.abb.2011.12.008.

(21) Alfonso-Prieto, M.; Biarnés, X.; Vidossich, P.; Rovira, C. The Molecular Mechanism of the Catalase Reaction. Journal of the American Chemical Society 2009, $131 \quad$ (33), 11751-11761. https://doi.org/10.1021/ja9018572.

(22) Zhang, J. Synthesis, Crystal Structure and Properties of a New Dinuclear Manganese(III) Complex: A Mimic for Catalase. Journal of Inorganic Biochemistry 2001, $86 \quad$ (2-3), 573-579. https://doi.org/10.1016/S0162-0134(01)00209-4.

(23) Barynin, V. V.; Whittaker, M. M.; Antonyuk, S. V.; Lamzin, V. S.; Harrison, P. M.; Artymiuk, P. J.; Whittaker, J. W. Crystal Structure of Manganese Catalase from Lactobacillus Plantarum. Structure 2001, 9 (8), 725-738. https://doi.org/10.1016/S0969-2126(01)00628-1.

(24) Poulos, T. Peroxidase and Catalase. In Biological Inorganic Chemistry; Bertini, I., Gray, H. B., Stiefel, E. I., Valentine, J. S., Eds. Universty Science Book: Sausalito, 2007.

(25) Browett, W. R.; Stillman, M. J. MAGNETIC CIRCULAR DICHROISM STUDIES ON THE ELECTRONIC CONFIGURATION OF CATALASE COMPOUNDS I AND II. Biochim. Biophys. Acta Prot. Struct. 1980, 623 (1), 21-31. https://doi.org/10.1016/00052795(80)90004-5.

(26) Allgood, G. S.; Perry, J. J. Characterization of a ManganeseContaining Catalase from the Obligate Thermophile Thermoleophilum Album t. J. BACTERIOL. 1986, 168, 5 .

(27) Antonyuk, S. V.; Melik-Adamyan, V. R.; Popov, A. N.; Lamzin, V. S.; Hempstead, P. D.; Harrison, P. M.; Artymyuk, P. J.; Barynin, V. V. Three-Dimensional Structure of the Enzyme Dimanganese Catalase from Thermus Thermophilus at $1 \AA$ Resolution. Crystallogr. Rep. 2000, 45 (1), 105-116. https://doi.org/10.1134/1.171145.

(28) Fisher, A. E. O.; Maxwell, S. C.; Naughton, D. P. Catalase and Superoxide Dismutase Mimics for the Treatment of Inflammatory Diseases. Inorganic Chemistry Communications 2003, 6 (9), 1205-1208. https://doi.org/10.1016/S1387-7003(03)00223-5.

(29) Tovmasyan, A.; Maia, C. G. C.; Weitner, T.; Carballal, S.; Sampaio, R. S.; Lieb, D.; Ghazaryan, R.; Ivanovic-Burmazovic, I.; FerrerSueta, G.; Radi, R.; Reboucas, J. S.; Spasojevic, I.; Benov, L.; BatinicHaberle, I. A Comprehensive Evaluation of Catalase-like Activity of Different Classes of Redox-Active Therapeutics. Free Radical Biology and Medicine 2015, 86, 308-321. https://doi.org/10.1016/j.freeradbiomed.2015.05.018.

(30) MacLean, L.; Karcz, D.; Jenkins, H.; McClean, S.; Devereux M.; Howe, O.; Pereira, M. D.; May, N. V.; Enyedy, É. A.; Creaven, B. S. Copper(II) Complexes of Coumarin-Derived Schiff Base Ligands: Pro- or Antioxidant Activity in MCF-7 Cells? Journal of Inorganic Biochemistry 2019, 197, 110702. https://doi.org/10.1016/j.jinorgbio.2019.110702.

(31) Signorella, S.; Hureau, C. Bioinspired Functional Mimics of the Manganese Catalases. Coordination Chemistry Reviews 2012, 256 (11-12), 1229-1245. https://doi.org/10.1016/j.ccr.2012.02.003.

(32) Sigel, H. Catalase and Peroxidase Activity of $\mathrm{Cu} 2+$ Complexes. Angewandte Chemie International Edition in English 1969, 8 (3), 167177. https://doi.org/10.1002/anie.196901671.

Kaizer, J.; Csay, T.; Speier, G.; Réglier, M.; Giorgi, M. Syn- thesis, Structure and Catalase-like Activity of $\mathrm{Cu}(\mathrm{N}-\mathrm{Baa}) 2(\mathrm{Phen})$ (Phen=1,10-Phenanthroline, N-BaaH=N-Benzoylanthranilic Acid). Inor ganic Chemistry Communications 2006, 9 (10), 1037-1039. https://doi.org/10.1016/j.inoche.2006.06.005.

(34) Ramadan, A. E.-M. M. Syntheses and Characterization of New Tetraazamacrocyclic Copper(II) Complexes as a Dual Functional Mimic Enzyme (Catalase and Superoxide Dismutase). Journal of Coordination $\begin{array}{lllll}\text { Chemistry } & \text { 2012, } & 65 & \text { (8), }\end{array}$ https://doi.org/10.1080/00958972.2012.673719

(35) Pires, B. M.; Silva, D. M.; Visentin, L. C.; Rodrigues, B. L.; Carvalho, N. M. F.; Faria, R. B. Synthesis and Characterization of Cobalt(III), Nickel(II) and Copper(II) Mononuclear Complexes with the Ligand 1,3-Bis[(2-Aminoethyl)Amino]-2-Propanol and Their CatalaseLike Activity. PLoS ONE 2015, 10 (9), e0137926. https://doi.org/10.1371/journal.pone.0137926.

(36) Guerreiro, J. F.; Gomes, M. A. G. B.; Pagliari, F.; Jansen, J.; Marafioti, M. G.; Nistico, C.; Hanley, R.; Costa, R. O.; Ferreira, S. S.; Mendes, F.; Fernandes, C.; Horn, A.; Tirinato, L.; Seco, J. Iron and Copper Complexes with Antioxidant Activity as Inhibitors of the Metastatic Potential of Glioma Cells. RSC Adv. 2020, 10 (22), 12699-12710. https://doi.org/10.1039/D0RA00166J.

(37) Gao, J.; Martell, A. E.; Reibenspies, J. H. Novel Dicopper(II) Catalase-like Model Complexes: Synthesis, Crystal Structure, Properties and Kinetic Studies. Inorganica Chimica Acta 2003, 346, 32-42. https://doi.org/10.1016/S0020-1693(02)01393-2.

(38) Ray, A.; Rosair, G. M.; Pilet, G.; Dede, B.; Gómez-García, C. J.; Signorella, S.; Bellú, S.; Mitra, S. Preferential Azido Bridging Regulating the Structural Aspects in Cobalt(III) and Copper(II)-Schiff Base Complexes: Syntheses, Magnetostructural Correlations and Catalytic Studies. Inorganica Chimica Acta 2011, 375 (1), 20-30. https://doi.org/10.1016/j.ica.2011.04.008.

(39) Caglar, S.; Adıgüzel, E.; Caglar, B.; Saykal, T.; Sahin, E.; Büyükgüngör, O. Synthesis, Crystal Structure, Spectroscopic, Thermal, Catechol Oxidase and Catalase-like Studies: New Copper(II) Complexes of 2-Benzoylbenzoate and 2-Pyridilpropanol Ligands. Inorganica Chimica Acta 2013, 397, 101-109. https://doi.org/10.1016/j.ica.2012.11.028.

(40) Tang, Q.; Wu, J.-Q.; Li, H.-Y.; Feng, Y.-F.; Zhang, Z.; Liang, Y.-N. Dinuclear $\mathrm{Cu}(\mathrm{II})$ Complexes Based on p-Xylylene-Bridged Bis(1,4,7-Triazacyclononane) Ligands: Synthesis, Characterization, DNA Cleavage Abilities and Evaluation of Superoxide Dismutase- and Catalase-like Activities. Applied Organometallic Chemistry 2018, 32 (5), e4297. https://doi.org/10.1002/aoc.4297.

(41) Singh, U. P.; Singh, R. K.; Isogai, Y.; Shiro, Y. Design and Synthesis of De Novo Peptide for Manganese Binding. International Journal of Peptide Research and Therapeutics 2006, 12 (4), 379-385. https://doi.org/10.1007/s10989-006-9042-3.

(42) Csire, G.; Timári, S.; Asztalos, J.; Király, J. M.; Kiss, M.; Várnagy, K. Coordination, Redox Properties and SOD Activity of Cu(II) Complexes of Multihistidine Peptides. Journal of Inorganic Biochemistry 2017, 177, 198-210. https://doi.org/10.1016/j.jinorgbio.2017.08.033.

(43) Vincent, A.; Fores, J. R.; Tauziet, E.; Quévrain, E.; Dancs, Á.; Conte-Daban, A.; Bernard, A.-S.; Pelupessy, P.; Coulibaly, K.; Seksik, P.; Hureau, C.; Selmeczi, K.; Policar, C.; Delsuc, N. An Easy-to-Implement Combinatorial Approach Involving an Activity-Based Assay for the Discovery of a Peptidyl Copper Complex Mimicking Superoxide Dismutase. Chem. Commun. 2020, 56 (3), 399-402. https://doi.org/10.1039/C9CC07920C.

(44) Mathieu, E.; Tolbert, A. E.; Koebke, K. J.; Tard, C.; Iranzo, O.; Penner- Hahn, J. E.; Policar, C.; Pecoraro, V. Rational De Novo Design of a $\mathrm{Cu}$ Metalloenzyme for Superoxide Dismutation. Chemistry - A Euro$\begin{array}{lllll}\text { pean } & \text { Journal } & \mathbf{2 0 2 0}, & 26 & \text { (1), 249-258. }\end{array}$ https://doi.org/10.1002/chem.201903808 
(45) Singh, U. P.; Singh, R. K.; Isogai, Y.; Shiro, Y. Design and Synthesis of De Novo Peptide for Manganese Binding. International Journal of Peptide Research and Therapeutics 2006, 12 (4), 379-385. https://doi.org/10.1007/s10989-006-9042-3.

(46) Medici, S.; Peana, M.; Delogu, L. G.; Zoroddu, M. A. Mn(Ii) and $\mathrm{Zn}$ (Ii) Interactions with Peptide Fragments from Parkinson's Disease Genes. Dalton Transactions 2012, 41 (15), 4378. https://doi.org/10.1039/c2dt12168a.

(47) Peana, M.; Medici, S.; Nurchi, V. M.; Crisponi, G.; Lachowicz, J. I.; Zoroddu, M. A. Manganese and Cobalt Binding in a Multi-Histidinic Fragment. Dalton Transactions 2013, 42 (46), 16293. https://doi.org/10.1039/c3dt51091c.

(48) Sóvágó, I.; Kállay, C.; Várnagy, K. Peptides as Complexing Agents: Factors Influencing the Structure and Thermodynamic Stability of Peptide Complexes. Coordination Chemistry Reviews 2012, 256 (19-20), 2225-2233. https://doi.org/10.1016/j.ccr.2012.02.026.

(49) Gonzalez, P.; Bossak, K.; Stefaniak, E.; Hureau, C.; Raibaut, L.; Bal, W.; Faller, P. N-Terminal Cu-Binding Motifs (Xxx-Zzz-His, XxxHis) and Their Derivatives: Chemistry, Biology and Medicinal Applications. Chemistry - A European Journal 2018, 24 (32), 8029-8041. https://doi.org/10.1002/chem.201705398.

(50) Franz, K. J.; Maglathlin, R. L.; Imperiali, B. A Powerful Combinatorial Screen to Identify High-Affinity Terbium(III)-Binding Peptides. ChemBioChem 2003, 4 (4), 272-276. https://doi.org/10.1002/cbic.200390047.

(51) Irving, H.; Williams, R. J. P. 637. The Stability of TransitionMetal Complexes. J. Chem. Soc. 1953, No. 0, 3192-3210. https://doi.org/10.1039/JR9530003192.

(52) Weydert, C. J.; Cullen, J. J. Measurement of Superoxide Dismutase, Catalase and Glutathione Peroxidase in Cultured Cells and Tissue. Nature Protocols 2010, 5 (1), 51-66. https://doi.org/10.1038/nprot.2009.197.

(53) Hoffmann, C.; Blechschmidt, D.; Krüger, R.; Karas, M.; Griesinger, C. Mass Spectrometric Sequencing of Individual Peptides from Combinatorial Libraries via Specific Generation of ChainTerminated Sequences. Journal of Combinatorial Chemistry 2002, 4 (1), 79-86. https://doi.org/10.1021/cc010057x.

(54) Bonomo, R. P. EPR Reinvestigation of the Copper(II)Imidazole System. Inorganic Chemistry 1988, 27 (14), 2510-2512.

(55) Valentine, J. S.; Mota de Freitas, D. Copper-Zinc Superoxide Dismutase: A Unique Biological "Ligand" for Bioinorganic Studies. Journal of Chemical Education 1985, 62 (11), 990. https://doi.org/10.1021/ed062p990.

(56) Pantoliano, M. W.; Valentine, J. S.; Nafie, L. A. Spectroscopic Studies of Copper(II) Bound at the Native Copper Site or Substituted at the Native Zinc Site of Bovine Erythrocuprein (Superoxide Dismutase). Journal of the American Chemical Society 1982, 104 (23), 6310-6317. https://doi.org/10.1021/ja00387a027.

(57) Peisach, J.; Blumberg, W. E. Structural Implications Derived from the Analysis of Electron Paramagnetic Resonance Spectra of Natural and Artificial Copper Proteins. Archives of Biochemistry and Biophysics 1974, 165 (2), 691-708. https://doi.org/10.1016/0003-9861(74)90298-7.

(58) Sakaguchi, U.; Addison, A. W. Spectroscopic and Redox Studies of Some Copper(II) Complexes with Biomimetic Donor Atoms: Implications for Protein Copper Centres. J. Chem. Soc., Dalton Trans. 1979, No. 4, 600. https://doi.org/10.1039/dt9790000600.

(59) Signorella, S.; Palopoli, C.; Ledesma, G. Rationally Designed Mimics of Antioxidant Manganoenzymes: Role of Structural Features in the Quest for Catalysts with Catalase and Superoxide Dismutase Activity. Coordination Chemistry Reviews 2018, 365, 75-102. https://doi.org/10.1016/j.ccr.2018.03.005.

(60) Balland, V.; Hureau, C.; Savéant, J.-M. Electrochemical and Homogeneous Electron Transfers to the Alzheimer Amyloid- $\beta$ Copper Complex Follow a Preorganization Mechanism. PNAS 2010, 107 (40), 17113-17118. https://doi.org/10.1073/pnas.1011315107.

(61) Mena, S.; Mirats, A.; Caballero, A. B.; Guirado, G.; Barrios, L. A.; Teat, S. J.; Rodriguez-Santiago, L.; Sodupe, M.; Gamez, P. Drastic Effect of the Peptide Sequence on the Copper-Binding Properties of Tripeptides and the Electrochemical Behaviour of Their Copper(II) Complexes. Chemistry - A European Journal 2018, 24 (20), 5153-5162. https://doi.org/10.1002/chem.201704623.

(62) Scheller, K. H.; Abel, T. H. J.; Polanyi, P. E.; Wenk, P. K.; Fischer, B. E.; Sigel, H. Metal Ion/Buffer Interactions. European Journal of Biochemistry 1980, 107 (2), 455-466. https://doi.org/10.1111/j.14321033.1980.tb06051.x

(63) Mash, H. E.; Chin, Y.-P.; Sigg, L.; Hari, R.; Xue, H Complexation of Copper by Zwitterionic Aminosulfonic (Good) Buffers. Anal. Chem. 2003, 75 (3), 671-677. https://doi.org/10.1021/ac0261101.

(64) Aronoff-Spencer, E.; Burns, C. S.; Avdievich, N. I.; Gerfen, G. J.; Peisach, J.; Antholine, W. E.; Ball, H. L.; Cohen, F. E.; Prusiner, S. B.; Millhauser, G. L. Identification of the $\mathrm{Cu} 2+$ Binding Sites in the NTerminal Domain of the Prion Protein by EPR and CD Spectroscopy. Biochemistry 2000, 39 (45), 13760-13771.

(65) Alies, B.; Renaglia, E.; Rózga, M.; Bal, W.; Faller, P.; Hureau, C. $\mathrm{Cu}(\mathrm{II})$ Affinity for the Alzheimer's Peptide: Tyrosine Fluorescence Studies Revisited. Analytical Chemistry 2013, 85 (3), 1501-1508. https://doi.org/10.1021/ac302629u.

(66) Boeri Erba, E.; Zenobi, R. Mass Spectrometric Studies of Dissociation Constants of Noncovalent Complexes. Annual Reports Section "C" (Physical Chemistry) 2011, 107 (0), 199-228. https://doi.org/10.1039/C1PC90006D.

(67) S. Scheller, J.; W. Irvine, G.; L. Wong, D.; Hartwig, A.; J. Stillman, M. Stepwise Copper( i ) Binding to Metallothionein: A Mixed Cooperative and Non-Cooperative Mechanism for All 20 Copper Ions. Metallomics 2017, 9 (5), 447-462. https://doi.org/10.1039/C7MT00041C.

(68) Ott, D. B.; Hartwig, A.; Stillman, M. J. Competition between $\mathrm{Al} 3+$ and $\mathrm{Fe} 3+$ Binding to Human Transferrin and Toxicological Implications: Structural Investigations Using Ultra-High Resolution ESI MS and CD Spectroscopy. Metallomics 2019, 11 (5), 968-981. https://doi.org/10.1039/C8MT00308D.

(69) Dong, S.; Shirzadeh, M.; Fan, L.; Laganowsky, A.; Russell, D. $\mathrm{H}$. Ag+ Ion Binding to Human Metallothionein-2A Is Cooperative and Domain Specific. Anal. Chem. 2020, 92 (13), 8923-8932. https://doi.org/10.1021/acs.analchem.0c00829.

(70) Shank, M.; Barynin, V.; Dismukes, G. C. Protein Coordination to Manganese Determines the High Catalytic Rate of Dimanganese Catalases. Comparison to Functional Catalase Mimics http://pubs-acsorg/doi/pdf/10.1021/bi00255a025 (accessed Feb 15, 2021). https://doi.org/10.1021/bi00255a025.

(71) Belousov, V. V.; Fradkov, A. F.; Lukyanov, K. A.; Staroverov, D. B.; Shakhbazov, K. S.; Terskikh, A. V.; Lukyanov, S. Genetically Encoded Fluorescent Indicator for Intracellular Hydrogen Peroxide. Nat Methods 2006, 3 (4), 281-286. https://doi.org/10.1038/nmeth866.

(72) Mishina, N. M.; Markvicheva, K. N.; Bilan, D. S.; Matlashov, M. E.; Shirmanova, M. V.; Liebl, D.; Schultz, C.; Lukyanov, S.; Belousov, V. V. Chapter Three - Visualization of Intracellular Hydrogen Peroxide with HyPer, a Genetically Encoded Fluorescent Probe. In Methods in Enzymology; Cadenas, E., Packer, L., Eds.; Hydrogen Peroxide and Cell Signaling, Part A; Academic Press, 2013; Vol. 526, pp 45-59. https://doi.org/10.1016/B978-0-12-405883-5.00003-X 
(73) Gauron, C.; Meda, F.; Dupont, E.; Albadri, S.; Quenech'Du, N.; Ipendey, E.; Volovitch, M.; Del Bene, F.; Joliot, A.; Rampon, C.; Vriz, $\mathrm{S}$. Hydrogen Peroxide (H2O2) Controls Axon Pathfinding during Zebrafish Development. Developmental Biology 2016, 414 (2), 133-141. https://doi.org/10.1016/j.ydbio.2016.05.004.

(74) Vincent, A.; Thauvin, M.; Quévrain, E.; Mathieu, E.; Layani, S.; Seksik, P.; Batinic-Haberle, I.; Vriz, S.; Policar, C.; Delsuc, N. Evaluation of the Compounds Commonly Known as Superoxide Dismutase and Catalase Mimics in Cellular Models. Journal of Inorganic Biochemistry 2021, 111431. https://doi.org/10.1016/j.jinorgbio.2021.111431.

(75) Winterbourn, C. C. Biological Production, Detection, and Fate of Hydrogen Peroxide. Antioxidants \& Redox Signaling 2018, 29 (6), 541551. https://doi.org/10.1089/ars.2017.7425.

(76) Amblard, I.; Thauvin, M.; Rampon, C.; Queguiner, I.; Pak, V. V.; Belousov, V.; Prochiantz, A.; Volovitch, M.; Joliot, A.; Vriz, S. H 2 O 2 and Engrailed 2 Paracrine Activity Synergize to Shape the Zebrafish
Optic Tectum. Communications Biology 2020, 3 (1), 1-9. https://doi.org/10.1038/s42003-020-01268-7.

(77) Melenbacher, A.; C. Korkola, N.; J. Stillman, M. The Pathways and Domain Specificity of $\mathrm{Cu}$ ( i ) Binding to Human Metallothionein 1A. Metallomics 2020. https://doi.org/10.1039/D0MT00215A.

(78) Ngu, T. T.; Easton, A.; Stillman, M. J. Kinetic Analysis of Arsenic-Metalation of Human Metallothionein: Significance of the TwoDomain Structure. J. Am. Chem. Soc. 2008, 130 (50), 17016-17028. https://doi.org/10.1021/ja8060326.

(79) Tighe, A.; Staples, O.; Taylor, S. Mps1 Kinase Activity Restrains Anaphase during an Unperturbed Mitosis and Targets Mad2 to $\begin{array}{lllllll}\text { Kinetochores. } \quad J \quad \text { Cell Biol } & \mathbf{2 0 0 8}, & 181 & \text { (6), } & 893-901\end{array}$ https://doi.org/10.1083/jcb.200712028. 

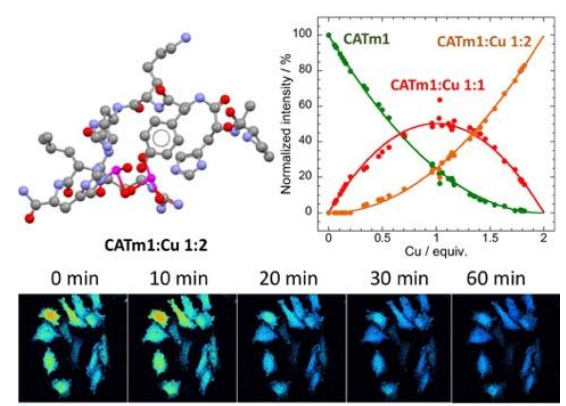

$\mathrm{H}_{2} \mathrm{O}_{2}$

Efficiently selected! A combinatorial approach associated with an activity-based screening led to the discovery of the first peptidyl di copper complex mimicking Catalase activity. This complex accelerates $\mathrm{H}_{2} \mathrm{O}_{2}$ dismutation into $\mathrm{O}_{2}$ and $\mathrm{H}_{2} \mathrm{O}$ in test tubes and in cells. 